\title{
Silicon uptake and supply during a Southern Ocean iron fertilization experiment (EIFEX) tracked by $\mathrm{Si}$ isotopes
}

\author{
A.-J. Cavagna, ${ }^{a},{ }^{*}$ F. Fripiat,,${ }^{b}$, F. Dehairs, ${ }^{a}$ D. Wolf-Gladrow,${ }^{d}$ B. Cisewski, ${ }^{d}$ N. Savoye $,{ }^{a}, 1$ L. André,b \\ and D. Cardinalb,2
}

${ }^{a}$ Earth and System Sciences \& Analytical and Environmental Chemistry, Vrije Universiteit Brussel, Brussels, Belgium

b Department of Geology and Mineralogy, Section of Mineralogy and Petrography, Royal Museum for Central Africa, Tervuren, Belgium

${ }^{\mathrm{c}}$ Department des Sciences de la Terre et de l'Environnement, Université Libre de Bruxelles, Brussels, Belgium

d Alfred Wegener Institute, Bremerhaven, Germany

\begin{abstract}
We studied the evolution of the isotopic composition of dissolved $\mathrm{Si}\left(\delta^{30} \mathrm{Si}_{\mathrm{DSi}}\right)$ and biogenic $\mathrm{Si}\left(\delta^{30} \mathrm{Si}_{\mathrm{BSi}}\right) \mathrm{during}$ a diatom bloom induced by an iron fertilization experiment in a Southern Ocean (SO) eddy. Dissolved Si (DSi) consumption was clearly boosted as a result of iron addition. We estimate an apparent $\mathrm{Si}$ isotopic fractionation factor of $-1.36 \% \pm 0.11 \%$, not significantly different from estimates based on in vitro incubations under $\mathrm{Fe}$ replete conditions and in agreement with previous SO studies under Fe-depleted conditions. The temporal variations of the $\delta^{30} \mathrm{Si}$ are best reconstructed considering the fertilized surface waters as an open system, i.e., DSi is continuously supplied from the winter water. Using vertical diffusivity, we estimate a supply of $6.7 \pm 1.2 \mathrm{mmol}$ $\mathrm{Si} \mathrm{m} \mathrm{m}^{-2} \mathrm{~d}^{-1}$ representing $30 \% \pm 5 \%$ of total DSi demand. We estimate biogenic silica (BSi) production at $22.1 \pm$ $1.8 \mathrm{mmol} \mathrm{Si} \mathrm{m}^{-2} \mathrm{~d}^{-1}$, similar to BSi production under natural conditions in the SO. The DSi use preceding the start of the fertilization was conservatively estimated at $49 \% \pm 4 \%$, and as a result of the Fe-fertilization, a further $31 \% \pm 4 \%$ of the initial DSi reservoir was consumed. The BSi export was estimated to be $17.4 \pm 1.7 \mathrm{mmol} \mathrm{Si}$ $\mathrm{m}^{-2} \mathrm{~d}^{-1}$. Our results suggest that for this study three main processes were acting significantly on $\delta^{30} \mathrm{Si}$ signatures, biological uptake, Si supply from subsurface, and export of BSi, and that the magnitude of production and export in such a Fe-fertilized experiment are similar to those for natural diatom blooms occurring in the Southern Ocean.
\end{abstract}

Upwelling of nutrient-rich waters south of the Antarctic polar front (APF) combined with phytoplankton growth under strong colimitation by iron (Fe) and light lead to large unused surface water nutrient concentrations, characterizing the Southern Ocean (SO) as a high nutrient low chlorophyll (HNLC) system (Martin 1990; Falkowski et al. 1998; Sarmiento et al. 2004). The current Fe limitation in the Southern Ocean has important implications for the potential of the biological carbon pump in significantly contributing to the $\mathrm{CO}_{2}$ sink strength of this ocean (Martin 1990; Watson et al. 2000; Brzezinski et al. 2002). The importance of this condition has triggered a series of in vitro Fe enrichment studies (Takeda 1998; Boyd et al. 2001), mesoscale iron fertilization experiments (see reviews by de Baar et al. 2005, 2008; Boyd et al. 2007), and natural iron fertilization studies (Blain et al. 2007; Pollard et al. 2007, 2009). Fe addition experiments (in short FeAX) generally resulted in a large increase in chlorophyll $a(\mathrm{Chl}$ $a$ ), as well as a shift in phytoplanktonic community toward

*Corresponding author: acavagna@vub.ac.be

Present addresses:

${ }^{1}$ Unité Mixte de Recherche 5805 Environnements et Paléoenvironnements Océaniques (EPOC), Université Bordeaux 1, Centre National de la Recherche Scientifique, Station Marine d'Arcachon, Arcachon, France

${ }^{2}$ Laboratoire d'Océanographie et du Climat: Expérimentation et Approches Numériques LOCEAN, Institut Pierre Simon Laplace, Université Pierre et Marie Curie, Paris, France dominance of diatoms. These experiments revealed a strong decrease in surface $p \mathrm{CO}_{2}$ during the course of the bloom, confirming that primary production (PP) in HNLC areas is Fe limited (de Baar et al. 2005, 2008; Boyd et al. 2007). To quantify past, current, and future oceanic carbon sequestration capacity in the context of climate change, FeAXs can thus provide extremely useful information.

The study of the Southern Ocean Si-biogeochemical cycle is crucial, since diatoms are the major primary producers (Nelson et al. 1995; Brzezinski et al. 2001; Quéguiner and Brzezinski 2002). As long as silicic acid $\left(\mathrm{H}_{4} \mathrm{SiO}_{4}\right.$, hereafter $\left.\mathrm{DSi}\right)$ is not limiting, diatoms will respond to enhanced Fe input in the HNLC Southern Ocean (Coale et al. 2004; Brzezinski et al. 2005; Boyd et al. 2007). Since diatoms preferentially take up light $\mathrm{Si}$ isotopes, thereby enriching the DSi pool with heavy isotopes (De La Rocha et al. 1997), information on the silicon isotopic composition $\left(\delta^{30} \mathrm{Si}\right)$ enables us to provide information on DSi sources, biological uptake, and advective supply for both the modern and the paleo-ocean (e.g., De La Rocha et al. 1998; Varela et al. 2004; Fripiat et al. in press). Controlled laboratory experiments (De La Rocha et al. 1997; Milligan et al. 2004) and field studies (De La Rocha et al. 2000; Varela et al. 2004; Cardinal et al. 2005) suggest a constant $\mathrm{Si}$ isotopic fractionation factor $(\varepsilon)$ between the product (biogenic silica, hereafter $\mathrm{BSi}$ ) and the source (DSi). However, the rather large standard deviation on this $\varepsilon$ value $(-1.1 \%$ $\pm 0.4 \%$ ) leads to large uncertainties in dissolved Si use estimates. A recent study highlights that 
BSi dissolution discriminates against heavy $\mathrm{Si}$ isotopes with a factor half the one due to uptake $(\varepsilon=-0.55 \%$ o $\pm 0.05 \%$; Demarest et al. 2009). As pointed out by Demarest et al., such dissolution-induced fractionation acts opposite to the one associated with BSi production and would thus reduce the overall fractionation.

We report here for the first time the temporal evolution of the particulate and dissolved silicon isotopic compositions during a diatom bloom induced by artificial $\mathrm{Fe}$ fertilization in the Southern Ocean. The European iron fertilization experiment (EIFEX) was conducted in the Antarctic circumpolar current to study the processes controlling the fate of the organic matter produced during this FeAX. Following fertilization, the phytoplankton became dominated by diatoms, $\mathrm{Chl} a$ increased more than fivefold, and particulate organic carbon (POC) nearly doubled (Hoffmann et al. 2006). Compared with previous FeAXs, EIFEX is unique because (1) it was carried out in a mesoscale eddy in order to minimize dilution of the fertilized patch by advection (Cisewski et al. 2008); (2) the long observation period ( $37 \mathrm{~d}$ ) encompassed the entire bloom, up to its demise (Hoffmann et al. 2006; Croot et al. 2007); and (3) the whole water column was studied to better constrain the fate of organic carbon and the importance of deep export and mesopelagic remineralization (Jacquet et al. 2008).

Our primary objective was to follow $\delta^{30} \mathrm{Si}$ variations during a phytoplankton bloom in order to evaluate the relative importance of the different processes controlling the Si cycle. We show that silicon isotopes not only allow identification of the DSi sources and modes of supply, but also help to constrain quantification of supply, consumption, and export.

\section{Methods}

Main hydrological features and sampling strategy-The data used in this study were collected in the vicinity of the Antarctic polar front (APF) during R/V Polarstern cruise ANT-XXI/3, which took place between 21 January and 25 March 2004. The EIFEX experiment was carried out in Lagrangian mode within a cyclonic eddy having a diameter of approximately $100 \mathrm{~km}$. The eddy, centered at about $2^{\circ} 15^{\prime} \mathrm{E}-49^{\circ} 15^{\prime} \mathrm{S}$, was shed from the APF by detachment of a northward protruding meander (Strass et al. 2005; Cisewski et al. 2008).

One day before the iron fertilization (day -1) initial sampling took place to determine the prefertilization conditions. On 13 February 2004 (day 0) the eddy was fertilized with $7 \times 10^{3} \mathrm{~kg}$ of $\mathrm{FeSO}_{4}$. A second fertilization was performed on day 13 because iron concentration had decreased approaching again limiting levels. The eddy was monitored for a total of $37 \mathrm{~d}$ using different parameters including fluorescence of Chl $a$ (chlorophyll sensitive light detection and ranging [LIDAR] system; Cembella et al. 2005) and fast-repetition-rate-fluorescence (FastTracka; Röttgers et al. 2005) to distinguish fertilized from unfertilized waters. Stations within the fertilized patch are referred to as IN-patch stations, while the so-called OUTpatch stations were located inside the eddy but outside the
Table 1. Biogenic silica content $(\mu \mathrm{mol} \mathrm{L}-1)$ and $\delta^{30} \mathrm{Si}_{\mathrm{BSi}}(\%$ ) for IN and OUT-patch stations. Number of measurements $(n)$ is provided; error is the standard deviation on replicates when $n=2$ and is the analytical standard error when $n=1$. Note that BSi was not sampled at Sta. 54463 and Sta. 48412.

\begin{tabular}{ccccc}
\hline \hline Station & $\begin{array}{c}\text { Depth } \\
(\mathrm{m})\end{array}$ & $\begin{array}{c}\mathrm{BSi} \\
\left(\mu \mathrm{mol} \mathrm{L}{ }^{-1}\right)\end{array}$ & $\begin{array}{c}\delta^{30} \mathrm{Si} \pm 1 \sigma_{\mathrm{SD}} \\
(\%)\end{array}$ & $n$ \\
\hline IN-patch & & & & \\
424 17 (day -1) & 10 & 2.1 & $1.00 \pm 0.06$ & 2 \\
& 40 & 2.3 & $0.81 \pm 0.04$ & 2 \\
508 16 (day 10) & 10 & 3.1 & $0.87 \pm 0.07$ & 1 \\
& 50 & 3.3 & $0.96 \pm 0.08$ & 1 \\
543 8 (day 21) & 10 & 4.0 & $1.07 \pm 0.08$ & 1 \\
& 30 & 2.7 & $1.19 \pm 0.07$ & 1 \\
55310 (day 28) & 10 & 5.8 & $1.21 \pm 0.08$ & 1 \\
& 40 & 5.5 & $1.26 \pm 0.07$ & 1 \\
59312 (day 36) & 10 & 5.7 & $1.80 \pm 0.11$ & $1^{*}$ \\
& 40 & $2.6(* *)$ & $1.47 \pm 0.10$ & $1^{*}$ \\
OUT-patch & & & & \\
509 13 (day 11) & 10 & 4.1 & $0.93 \pm 0.07$ & 1 \\
& 50 & 3.1 & $1.15 \pm 0.08$ & 1 \\
546 14 (day 25) & 10 & 1.7 & $1.59 \pm 0.09$ & $1^{*}$ \\
& 40 & 1.6 & $1.76 \pm 0.10$ & $1^{*}$ \\
587 10 (day 34) & 10 & 1.4 & $1.71 \pm 0.10$ & $1^{*}$ \\
& 40 & 1.4 & $1.69 \pm 0.09$ & $1^{*}$ \\
\hline
\end{tabular}

* $\delta^{29} \mathrm{Si}$ measurements.

Day, days after fertilization.

** BSi outlier (see Results and Discussion).

fertilized patch. For particulate biogenic $\mathrm{Si}$ isotopic composition $\left(\delta^{30} \mathrm{Si}_{\mathrm{BSi}}\right)$ surface water (upper $\left.50 \mathrm{~m}\right)$ was sampled at five stations IN-patch and three stations OUTpatch (Table 1). For dissolved $\mathrm{Si}$ isotopic composition $\left(\delta^{30} \mathrm{Si}_{\mathrm{DSi}}\right)$ six stations were sampled IN-patch and four stations OUT-patch from surface to $1000 \mathrm{~m}$ (Table 2).

Water sampling and analysis-Seawater was collected using Niskin bottles mounted on a conductivity, temperature, and depth (CTD) Rosette. Dissolved Si concentrations (DSi) were measured on board (within $24 \mathrm{~h}$ after sampling) using a colorimetric method (Hansen and Koroleff 1999) on a Technicon II autoanalyzer. Samples for $\mathrm{Si}$ isotopic composition were directly filtered through $0.4-\mu \mathrm{m}$ polycarbonate membranes (47 or $90 \mathrm{~mm}$ diameter) in closed plastic filtration units. Filtrates were stored in acid-cleaned polycarbonate bottles at room temperature in the dark, and filters were dried at $50^{\circ} \mathrm{C}$ and stored in plastic Petri dishes at room temperature. Samples were processed after return to the laboratory (Royal Museum for Central Africa [RMCA]).

For biogenic silica we applied a wet-alkaline digestion on one-fourth of the filter with $0.2 \mathrm{~mol} \mathrm{~L}^{-1} \mathrm{NaOH}$ (sodium hydroxide) solution ( $\mathrm{pH} \mathrm{13.3)}$ at $100^{\circ} \mathrm{C}$ during $40 \mathrm{~min}$ (adapted from Ragueneau et al. 2005). Since this digestion can dissolve some lithogenic silica, aluminum (a lithogenic source tracer) was analyzed in the leachates to check for possible lithogenic Si contribution. The latter was found negligible for all samples ( $\mathrm{Si}: \mathrm{Al}$ mass ratios $>650$, compared with a mean crust ratio of 3.4). Silicic acid concentration in the leachates was measured by colorimetry 
Table 2. Dissolved Si content $(\mu \mathrm{mol} \mathrm{L}-1)$ and $\delta^{30} \mathrm{Si}_{\mathrm{DSi}}(\%)$ for IN and OUT-patch stations. $n=$ number of measurements; error is the standard deviation on replicates when $n=2$ and is the analytical standard error when $n=1$.

\begin{tabular}{|c|c|c|c|c|}
\hline Station & $\begin{array}{l}\text { Depth } \\
(\mathrm{m})\end{array}$ & $\begin{array}{c}\mathrm{DSi} \\
\left(\mu \mathrm{mol} \mathrm{L}^{-1}\right)\end{array}$ & $\begin{array}{c}\delta^{30} \mathrm{Si} \pm 1 \sigma_{\mathrm{SD}} \\
(\% 0)\end{array}$ & $n$ \\
\hline \multicolumn{5}{|l|}{ IN-patch } \\
\hline day -1 & 10 & 18.9 & $2.13 \pm 0.11$ & $2 *$ \\
\hline $2.3^{\circ} \mathrm{E} ; 49.4^{\circ} \mathrm{S}$ & 40 & 18.9 & $2.34 \pm 0.12$ & $2 *$ \\
\hline \multirow[t]{11}{*}{42417} & 80 & 19.5 & $2.30 \pm 0.00$ & $2 *$ \\
\hline & 100 & 20.0 & $2.37 \pm 0.21$ & $2 *$ \\
\hline & 115 & 19.2 & $2.04 \pm 0.07$ & $1 *$ \\
\hline & 130 & 26.9 & $1.96 \pm 0.07$ & $1 *$ \\
\hline & 200 & 32.6 & $1.75 \pm 0.08$ & $1 *$ \\
\hline & 250 & 40.9 & $1.65 \pm 0.06$ & 1 \\
\hline & 350 & 59.4 & $1.71 \pm 0.07$ & $1 *$ \\
\hline & 400 & 68.7 & $1.53 \pm 0.06$ & 1 \\
\hline & 500 & 74.7 & $1.47 \pm 0.07$ & 1 \\
\hline & 800 & 82.4 & $1.47 \pm 0.06$ & $1 *$ \\
\hline & 1000 & 83.7 & $1.59 \pm 0.06$ & 1 \\
\hline day 10 & 10 & 15.9 & $2.42 \pm 0.12$ & $2 *$ \\
\hline $2.1^{\circ} \mathrm{E} ; 49.2^{\circ} \mathrm{S}$ & 50 & 15.9 & $2.41 \pm 0.08$ & $2 *$ \\
\hline \multirow{13}{*}{50816} & 60 & 16.1 & $2.63 \pm 0.05$ & $2 *$ \\
\hline & 90 & 16.8 & $2.65 \pm 0.25$ & $2 *$ \\
\hline & 120 & 22.6 & $2.23 \pm 0.07$ & $1 *$ \\
\hline & 150 & 28.2 & $2.22 \pm 0.07$ & $1 *$ \\
\hline & 200 & 33.4 & $1.51 \pm 0.07$ & $1 *$ \\
\hline & 250 & 41.7 & $1.53 \pm 0.05$ & 1 \\
\hline & 300 & 51.4 & $1.26 \pm 0.08$ & $1 *$ \\
\hline & 400 & 64.9 & $1.10 \pm 0.06$ & $1 *$ \\
\hline & 450 & 70.0 & $1.43 \pm 0.26$ & 2 \\
\hline & 500 & 72.7 & $1.29 \pm 0.07$ & $1 *$ \\
\hline & 600 & 77.3 & $1.25 \pm 0.07$ & $1 *$ \\
\hline & 800 & 81.3 & $1.39 \pm 0.10$ & $1 *$ \\
\hline & 1000 & 83.5 & $1.18 \pm 0.06$ & $1 *$ \\
\hline day 21 & 10 & 12.5 & $2.41 \pm 0.10$ & $2 *$ \\
\hline $2.5^{\circ} \mathrm{E} ; 49.5^{\circ} \mathrm{S}$ & 30 & 12.4 & $2.53 \pm 0.15$ & $2 *$ \\
\hline \multirow[t]{11}{*}{5438} & 60 & 12.4 & $2.42 \pm 0.08$ & $2 *$ \\
\hline & 120 & 15.1 & $2.41 \pm 0.07$ & 1 \\
\hline & 150 & 23.9 & $1.59 \pm 0.06$ & $1 *$ \\
\hline & 200 & 30.7 & $1.62 \pm 0.07$ & $1 *$ \\
\hline & 250 & 37.3 & $1.38 \pm 0.06$ & $1 *$ \\
\hline & 350 & 54.9 & $1.07 \pm 0.07$ & $1 *$ \\
\hline & 400 & 61.5 & $1.10 \pm 0.09$ & $1 *$ \\
\hline & 500 & 68.2 & $1.29 \pm 0.07$ & $1 *$ \\
\hline & 600 & 71.3 & $1.12 \pm 0.06$ & $1 *$ \\
\hline & 700 & 71.2 & $1.19 \pm 0.06$ & $1 *$ \\
\hline & 800 & 74.2 & $1.32 \pm 0.08$ & $1 *$ \\
\hline day 23 & 10 & 10.8 & $3.35 \pm 0.09$ & 1 \\
\hline $1.9^{\circ} \mathrm{E} ; 49.4^{\circ} \mathrm{S}$ & 50 & 10.8 & $2.97 \pm 0.07$ & 1 \\
\hline \multirow[t]{7}{*}{54463} & 100 & 11.6 & $2.53 \pm 0.08$ & $1 *$ \\
\hline & 150 & 25.3 & $2.17 \pm 0.07$ & $1 *$ \\
\hline & 200 & 30.1 & $1.80 \pm 0.09$ & $1 *$ \\
\hline & 300 & 44.7 & $1.87 \pm 0.07$ & $1 *$ \\
\hline & 500 & 70.7 & $1.87 \pm 0.10$ & $1 *$ \\
\hline & 750 & 79.0 & $1.49 \pm 0.08$ & $1 *$ \\
\hline & 1000 & 82.2 & $1.55 \pm 0.07$ & $1 *$ \\
\hline day 28 & 10 & 9.3 & $2.70 \pm 0.16$ & $2 *$ \\
\hline $2.4^{\circ} \mathrm{E} ; 49.5^{\circ} \mathrm{S}$ & 40 & 9.3 & $2.65 \pm 0.16$ & $2 *$ \\
\hline
\end{tabular}

Table 2. Continued.

\begin{tabular}{|c|c|c|c|c|}
\hline Station & $\begin{array}{l}\text { Depth } \\
(\mathrm{m})\end{array}$ & $\begin{array}{c}\mathrm{DSi} \\
\left(\mu \mathrm{mol} \mathrm{L}^{-1}\right)\end{array}$ & $\begin{array}{c}\delta^{30} \mathrm{Si} \pm 1 \sigma_{\mathrm{SD}} \\
(\% 0)\end{array}$ & $n$ \\
\hline \multirow[t]{11}{*}{55310} & 60 & 9.5 & $2.37 \pm 0.06$ & 1 \\
\hline & 90 & 10.1 & $2.39 \pm 0.07$ & 1 \\
\hline & 150 & 20.7 & $1.90 \pm 0.07$ & $1 *$ \\
\hline & 200 & 31.7 & $1.77 \pm 0.06$ & 1 \\
\hline & 250 & 39.7 & $1.70 \pm 0.08$ & $1 *$ \\
\hline & 300 & 49.2 & $1.70 \pm 0.07$ & $1 *$ \\
\hline & 350 & 57.4 & $1.41 \pm 0.07$ & $1 *$ \\
\hline & 400 & 63.1 & $1.44 \pm 0.06$ & $1 *$ \\
\hline & 600 & 74.0 & $1.27 \pm 0.06$ & $1 *$ \\
\hline & 800 & 78.0 & $1.37 \pm 0.07$ & $1 *$ \\
\hline & 1000 & 79.2 & $1.35 \pm 0.07$ & $1 *$ \\
\hline day 36 & 10 & 7.5 & $2.83 \pm 0.07$ & $1 *$ \\
\hline $2.5^{\circ} \mathrm{E} ; 49.5^{\circ} \mathrm{S}$ & 60 & 7.5 & $2.98 \pm 0.07$ & $1 *$ \\
\hline \multirow[t]{10}{*}{59312} & 120 & 13.2 & $1.90 \pm 0.09$ & 1 \\
\hline & 150 & 24.0 & $1.54 \pm 0.11$ & 1 \\
\hline & 200 & 31.6 & $1.36 \pm 0.15$ & 1 \\
\hline & 250 & 35.8 & $1.40 \pm 0.10$ & $1 *$ \\
\hline & 300 & 42.7 & $1.56 \pm 0.09$ & $1 *$ \\
\hline & 350 & 51.0 & $1.51 \pm 0.07$ & $1 *$ \\
\hline & 450 & 64.6 & $1.30 \pm 0.06$ & $1 *$ \\
\hline & 500 & 69.0 & $1.10 \pm 0.07$ & $1 *$ \\
\hline & 600 & 73.2 & $1.19 \pm 0.07$ & $1 *$ \\
\hline & 1000 & 80.3 & $1.35 \pm 0.05$ & 2 \\
\hline \multicolumn{5}{|l|}{ OUT-patch } \\
\hline day 7 & 10 & 8.7 & $2.65 \pm 0.07$ & $1 *$ \\
\hline $2.9^{\circ} \mathrm{E} ; 49.4^{\circ} \mathrm{S}$ & 50 & 9.4 & $2.65 \pm 0.08$ & $1 *$ \\
\hline \multirow[t]{5}{*}{48412} & 150 & 24.2 & $1.69 \pm 0.07$ & $1 *$ \\
\hline & 300 & 42.3 & $1.58 \pm 0.06$ & $1 *$ \\
\hline & 500 & 63.0 & $1.49 \pm 0.14$ & 1 \\
\hline & 700 & 71.9 & $1.24 \pm 0.12$ & $2 *$ \\
\hline & 1000 & 76.8 & $1.25 \pm 0.07$ & $1 *$ \\
\hline day 11 & 10 & 13.8 & $2.64 \pm 0.21$ & 2 \\
\hline $2.0^{\circ} \mathrm{E} ; 49.0^{\circ} \mathrm{S}$ & 50 & 13.8 & $2.52 \pm 0.16$ & 2 \\
\hline \multirow[t]{4}{*}{50913} & 90 & 14.0 & $2.44 \pm 0.10$ & $2 *$ \\
\hline & 120 & 16.3 & $1.89 \pm 0.06$ & 1 \\
\hline & 150 & 19.7 & $2.07 \pm 0.07$ & 1 \\
\hline & 200 & 30.7 & $1.54 \pm 0.12$ & 1 \\
\hline day 25 & 10 & 8.4 & $2.54 \pm 0.07$ & $1 *$ \\
\hline $2.1^{\circ} \mathrm{E} ; 49.5^{\circ} \mathrm{S}$ & 40 & 8.4 & $2.52 \pm 0.08$ & $1 *$ \\
\hline \multirow[t]{3}{*}{54614} & 80 & 8.6 & $1.78 \pm 0.06$ & 1 \\
\hline & 115 & 15.7 & $1.89 \pm 0.11$ & 1 \\
\hline & 150 & 23.9 & $2.11 \pm 0.08$ & 1 \\
\hline day 34 & 10 & 9.8 & $2.52 \pm 0.07$ & $1 *$ \\
\hline $2.1^{\circ} \mathrm{E} ; 49.5^{\circ} \mathrm{S}$ & 40 & 9.7 & $3.00 \pm 0.08$ & $1 *$ \\
\hline \multirow[t]{8}{*}{58710} & 60 & 9.8 & $2.50 \pm 0.07$ & 1 \\
\hline & 80 & 10.7 & $2.04 \pm 0.06$ & 1 \\
\hline & 150 & 26.3 & $1.82 \pm 0.06$ & 1 \\
\hline & 250 & 40.5 & $1.74 \pm 0.08$ & 1 \\
\hline & 350 & 55.3 & $1.56 \pm 0.06$ & 1 \\
\hline & 500 & 70.4 & $1.24 \pm 0.06$ & 1 \\
\hline & 750 & 78.8 & $1.28 \pm 0.08$ & $1 *$ \\
\hline & 1000 & 81.3 & $1.10 \pm 0.06$ & $1 *$ \\
\hline
\end{tabular}

* $\delta^{29}$ Si measurements.

Day, days after fertilization. 
(Grasshof et al. 1983) using a Genesys 10S ultraviolet (UV) spectrophotometer.

The extraction protocol used for $\mathrm{Si}$ isotopes is inefficient at concentrations $<10 \mu \mathrm{mol} \mathrm{L}^{-1} \mathrm{DSi}$ (De La Rocha et al. 1996). For such samples we first applied a preconcentration step adapted from the magnesium induced coprecipitation (MAGIC) method (Karl and Tien 1992; Brzezinski et al. 2003; Cardinal et al. 2005). Briefly, DSi is precipitated along with brucite $\left(\mathrm{Mg}(\mathrm{OH})_{2}\right)$ by increasing the $\mathrm{pH}$ with Suprapur ammonium hydroxide $\left(\mathrm{NH}_{4} \mathrm{OH}\right)$, and this precipitate is redissolved in Suprapur hydrogen chloride $(\mathrm{HCl})$. Dissolved silicon (from both DSi and BSi) can then be extracted via its quantitative precipitation with triethylamine-molybdate (De La Rocha et al. 1996). After combustion of the silicomolybdate precipitate in covered platinum crucibles, the pure cristobalite phase was transferred to precleaned polypropylene vials. Dissolution of cristobalite was done in a dilute hydrogen fluoride (HF) and $\mathrm{HCl}$ mixture as described in Cardinal et al. (2003).

Silicon isotopic compositions (expressed relative to the NBS-28 quartz standard, National Institute of Standards and Technology [NIST] Reference Material 8546) were then measured on a $\mathrm{Nu}$ Plasma multicollector inductively coupled plasma mass spectrometer (MC-ICP-MS; Université Libre de Bruxelles [ULB] RMCA, Brussels) using Mg external doping in dry plasma mode (Cardinal et al. 2003). This method does not allow measurement of ${ }^{30} \mathrm{Si}$ because of overlap with ${ }^{14} \mathrm{~N}^{16} \mathrm{O}$ interference, so most of the measurements $(60 \%)$ were acquired as $\delta^{29} \mathrm{Si}(\%)$. Following an upgrade of the $\mathrm{Nu}$ Plasma instrument, high resolution and pseudo high resolution could be achieved allowing the measurement of both $\delta^{29} \mathrm{Si}$ and $\delta^{30} \mathrm{Si}$ as described in Abraham et al. (2008). In the following, results will be discussed using the ${ }^{30} \mathrm{Si}$ notation only. Samples for which only $\delta^{29} \mathrm{Si}$ was measured were converted into $\delta^{30} \mathrm{Si}$ using the theoretical conversion factor of 1.96, calculated from the kinetic fractionation law (Young et al. 2002; Brzezinski et al. 2006). The conversion factor calculated from EIFEX DSi and BSi samples, which were measured both as $\delta^{29} \mathrm{Si}$ and $\delta^{30} \mathrm{Si}$, is $1.98 \pm 0.08\left(R^{2}=0.94, p<0.05\right.$, not shown $)$. The reproducibility $\left( \pm 2 \sigma_{\mathrm{SD}}\right)$ of the two analytical methods described above is similar: $\pm 0.10 \% 0\left(\delta^{29} \mathrm{Si}\right)$ and $\pm 0.15 \%$ $\left(\delta^{30} \mathrm{Si}\right)$. Accuracy and reproducibility were checked on a daily basis and confirmed by several intercomparison studies on secondary reference materials such as diatomite (Cardinal et al. 2003; Reynolds et al. 2007; Abraham et al. 2008). Numerous analyses of this diatomite secondary reference material indicated that no significant isotopic bias occurred regardless of the method used.

\section{Results}

Our results for surface BSi concentration are in good agreement with other EIFEX BSi measurements (Hoffmann et al. 2006), showing an overall increase from 2.1 to $5.7 \mu \mathrm{mol} \mathrm{L}{ }^{-1} \mathrm{IN}$-patch over the course of the experiment (Table 1). One exception is sample 59312 (40 m, day 36), which shows a BSi concentration $\left(2.6 \mu \mathrm{mol} \mathrm{L}{ }^{-1}\right)$ half the one of nearby samples $59312(10 \mathrm{~m})$ and $55310(10 \mathrm{~m}$ and $40 \mathrm{~m})$ for which $\mathrm{BSi}$ concentration ranges between 5.5 and
$5.8 \mu \mathrm{mol} \mathrm{L}{ }^{-1}$ (Table 1). Sample $59312(40 \mathrm{~m})$ also differs from the value reported by Hoffmann et al. (2006) for a nearby cast $\left(5.8 \mu \mathrm{mol} \mathrm{L}^{-1} ; 20 \mathrm{~m}\right)$. This outlier was therefore not taken into account when calculating the average surface BSi concentrations shown in Table 3. However, since the $\delta^{30} \mathrm{Si}_{\mathrm{BSi}}$ signature of that particular sample does not show a significant deviation from the other signatures, it was not excluded when calculating the Table 3 average $\delta^{30} \mathrm{Si}_{\mathrm{BSi}}$ value.

Vertical variation - The upper layer of the eddy (upper $100 \mathrm{~m}$ ) was characterized by relatively warm and fresh Antarctic surface water. Between 200 and $300 \mathrm{~m}$ a subsurface temperature minimum layer or winter water (WW) was present. The WW is the remnant of the previous winter mixed layer water, capped by seasonal warming and freshening. The next major water mass below the WW was the upper circumpolar deep water (UCDW), characterized by an oxygen minimum and nutrient maxima (Whitworth and Nowlin 1987).

The behavior of $\delta^{30} \mathrm{Si}_{\mathrm{DSi}}$ is opposite to the one of [DSi] (Table 2; Fig. 1), with the former decreasing and the latter increasing with depth. With time, $\delta^{30} \mathrm{Si}_{\mathrm{DSi}}$ increases and DSi decreases. Surface $\delta^{30} \mathrm{Si}_{\mathrm{BSi}}$ stay systematically lighter than surface $\delta^{30} \mathrm{Si}_{\mathrm{DSi}}(+0.91 \%$ to $+1.61 \%$ vs. $+2.23 \%$ o to $+2.83 \%$, respectively; Table 3 ) with progress of the bloom.

The average mixed layer depth (MLD; $98 \pm 21 \mathrm{~m}$ ) reported by Cisewski et al. (2008) agrees well with the depth of the surface layer over which nutrient concentrations are homogenous (DSi, nitrate $\mathrm{NO}_{3}$, and phosphate $\mathrm{PO}_{4}$ ). Since no $\delta^{30} \mathrm{Si}_{\mathrm{BSi}}$ data are available for samples deeper than $50 \mathrm{~m}$, we restrict the direct comparison of $\delta^{30} \mathrm{Si}_{\mathrm{DSi}}$ and $\delta^{30} \mathrm{Si}_{\mathrm{BSi}}$ to this upper $50 \mathrm{~m}$, which, however, fits closely with the active mixed layer depth (mean AMLD $=66 \pm 29 \mathrm{~m}$ ) defined by Cisewski et al. (2008).

The complete DSi dataset for IN- and OUT-patch showing $\delta^{30} \mathrm{Si}_{\mathrm{DSi}}$ vs. DSi concentration (Fig. 2) gives an idea of the variability encountered during EIFEX. Note that the variability for surface water IN-patch is large compared with the one in the surface water OUT-patch (Fig. 2). WW, characterized by a temperature minimum (close to $1{ }^{\circ} \mathrm{C}$ ), is located between 200 and $300 \mathrm{~m}$, and we used the 250-m depth horizon as representative of WW (based on temperature-salinity [T-S] diagrams; not shown). For some stations we have no $\delta^{30} \mathrm{Si}_{\mathrm{DSi}}$ data at $250 \mathrm{~m}$, and in such cases, values were calculated by linear vertical interpolation, or values for closest depths were used to characterize WW (Table 3). The UCDW is characterized by a nutrient maximum between 500 and $1000 \mathrm{~m}$ (Tables 2, $3)$. Average $\left( \pm 1 \sigma_{\mathrm{SD}}\right) \mathrm{WW}$ and $\mathrm{UCDW} \delta^{30} \mathrm{Si}_{\mathrm{DSi}}$ and [DSi] values for combined IN- and OUT-patch stations are (Table 3; Fig. 2): $\mathrm{WW}_{\mathrm{IN}+\mathrm{OUT}}, \delta^{30} \mathrm{Si}_{\mathrm{DSi}}$ av $=1.61 \% \pm$ $0.16 \%$ and $[\mathrm{DSi}]_{\mathrm{av}}=37.3 \pm 2.8 \mu \mathrm{mol} \mathrm{L} \mathrm{L}^{-1}$; UCDW IN+OUT,$\delta^{30} \mathrm{Si}_{\mathrm{DSi}}$ av $=1.34 \% 0 \pm 0.16 \%$ and $[\mathrm{DSi}]_{\mathrm{av}}=75.5$ $\pm 3.2 \mu \mathrm{mol} \mathrm{L}^{-1}$ calculated from Table 2 . The standard deviations on these $\delta^{30} \mathrm{Si}_{\mathrm{DSi}}$ averages are twice as large as the analytical standard deviation $\left(1 \sigma_{\mathrm{SD}}=0.08 \%\right.$ ). This is probably due to the variability inherent to the complexity of the eddy structure.

Overall, our Si isotopic results for EIFEX surface water, WW, and UCDW compare well with results from other 
B) $\mathrm{BSi}\left(\mu \mathrm{mol} \mathrm{L}^{-1}\right)$

A) Sampling site

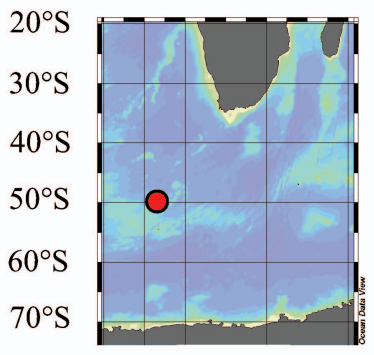

$0^{\circ} \quad 20^{\circ} \mathrm{E} \quad 40^{\circ} \mathrm{E}$

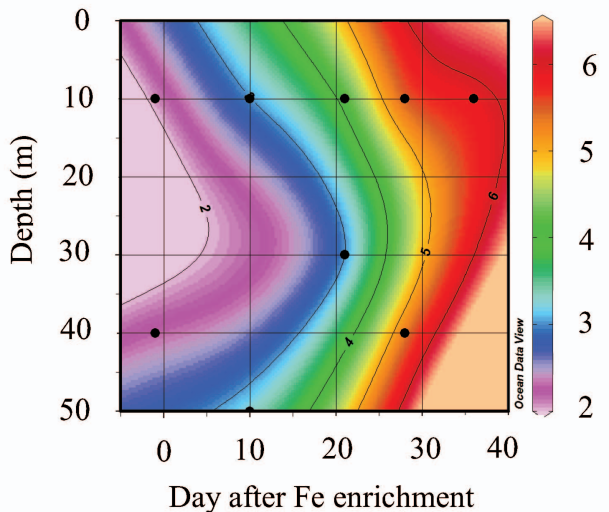

C) $\delta^{30} \mathrm{Si}_{\mathrm{BSi}}(\%)$

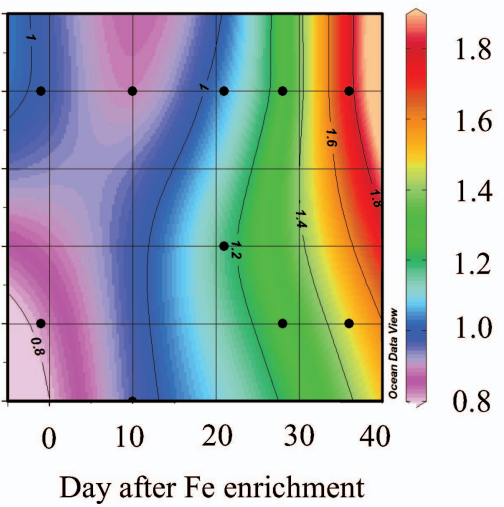

D) DSi $(\mu \mathrm{mol} \mathrm{L}-1)$

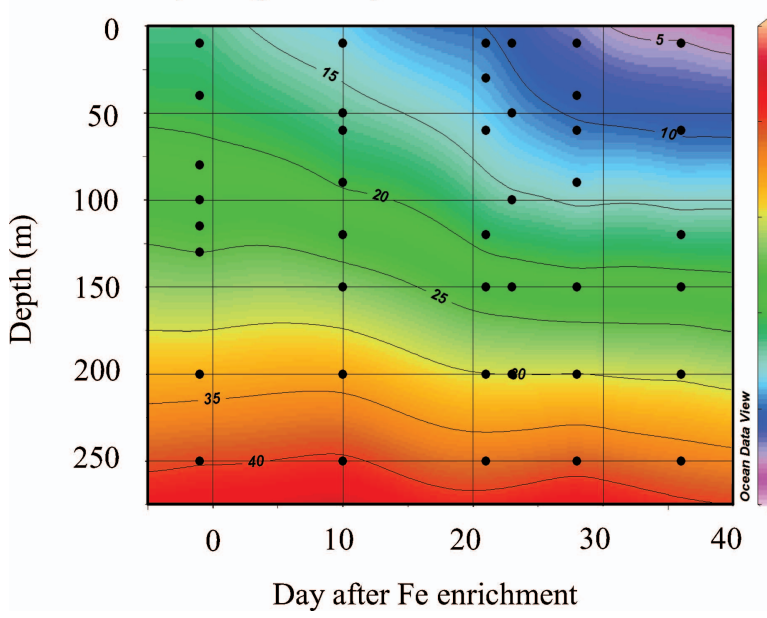

E) $\delta^{30} \mathrm{Si}_{\mathrm{DSi}}(\%)$

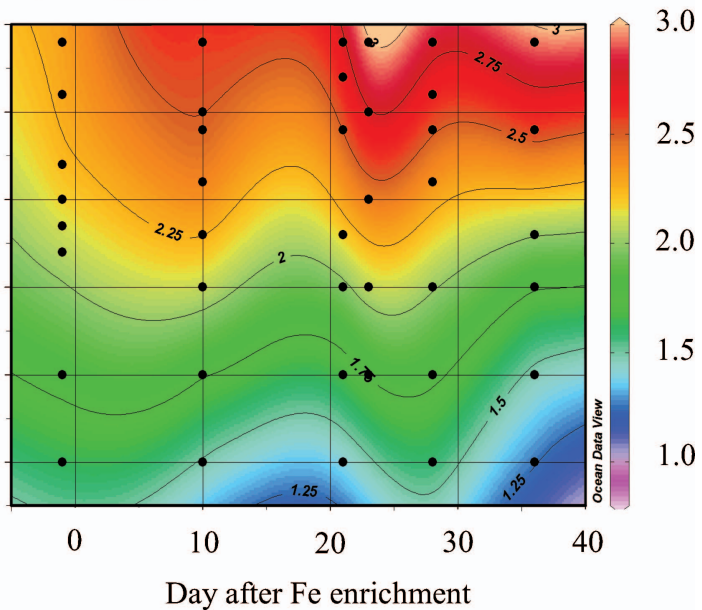

Fig. 1. (A) Sampling site; (B) surface to $50 \mathrm{~m}$ temporal variations of $\mathrm{BSi}\left(\mu \mathrm{mol} \mathrm{L}^{-1}\right)$; and (C) $\delta^{30} \mathrm{Si}_{\mathrm{BSi}}(\%)$; (D) surface to $275 \mathrm{~m}$ temporal variations of DSi $\left(\mu \mathrm{mol} \mathrm{L}{ }^{-1}\right)$; and (E) $\delta^{30} \mathrm{Si}_{\mathrm{DSi}}(\%)$. Figure elaborated using Ocean Data View version 4.2: R. Schlitzer, Ocean Data View, http://odv.awi.de.

Southern Ocean studies (Varela et al. 2004; Cardinal et al. 2007; Fripiat et al. in press).

Temporal variation in the surface waters during EIFEXThe surface water DSi contents are lower for the initial INpatch station before fertilization (Sta. 424 17, day -1) compared with the OUT-patch stations (all inside the eddy). This suggests the occurrence of large spatial gradients inside the eddy, possibly induced by the presence of filaments with different water properties or heterogeneity due the development and fate of a former bloom. However, as discussed below, the IN-patch temporal evolution of DSi concentration and isotopic composition in the surface water is consistent with the observed development of the induced bloom (Hoffmann et al. 2006) (Fig. 3A).

The major features of the temporal trends observed for IN-patch surface water (Fig. 3A) are an increase of $\delta^{30} \mathrm{Si}_{\mathrm{DSi}}$ (+ $0.60 \%$; from $2.23 \%$ o to $2.83 \%$ ) in parallel with a [DSi] decrease from 18.9 to $7.5 \mu \mathrm{mol} \mathrm{L}^{-1}$; an increase of $\delta^{30} \mathrm{Si}_{\mathrm{BSi}}$ (+ $0.70 \%$; from $0.9 \%$ to $1.6 \%$ ) in parallel with a [BSi] increase from 2.2 to $5.7 \mu \mathrm{mol} \mathrm{L}^{-1}$ (Fig. 3A; Table 3).
No clear temporal trends are observed for the OUTpatch temporal variations of $\delta^{30} \mathrm{Si}_{\mathrm{DSi}}$ and DSi (Fig. 3B). However, between days 10 and 27 we do observe a $\delta^{30} \mathrm{Si}_{\mathrm{BSi}}$ increase by $0.64 \%$ concomitant with a [BSi] decrease of $2.2 \mu \mathrm{mol} \mathrm{L}^{-1}$ (i.e., $>50 \%$ decrease).

\section{Discussion}

Temporal trends and outlier-The observed IN-patch temporal trends for $\delta^{30} \mathrm{Si}_{\mathrm{DSi}}, \delta^{30} \mathrm{Si}_{\mathrm{BSi}}$, Dsi, and $\mathrm{BSi}$ are in accordance with the well-known preferential uptake of light $\mathrm{Si}$ isotopes by diatoms (De La Rocha et al. 1997). Similar temporal variations are revealed when comparing $\delta^{30} \mathrm{Si}_{\mathrm{DSi}}$ and $\delta^{30} \mathrm{Si}_{\mathrm{BSi}}$ values between the Antarctic environment and Southern Ocean process study (AESOPS) and the Southern Ocean iron experiment cruises (Varela et al. 2004) and when comparing Antarctic circumpolar current (ACC) $\delta^{30} \mathrm{Si}$ values between spring (Cardinal et al. 2005, 2007) and summer cruises (Fripiat et al. in press). Sta. 544 63, day 23 $(+3.16 \%$ $\pm 0.09 \%)$ shows by far the heaviest surface water $\delta^{30} \mathrm{Si}_{\mathrm{DSi}}$ value and is thus classified as an outlier even if we do not know the cause for this large deviation from all 
Table 3. Average $\delta^{30} \mathrm{Si} \pm 1 \sigma_{\mathrm{SD}}(\%)$ and $\mathrm{Si}$ concentrations $\left(\mu \mathrm{mol} \mathrm{L}{ }^{-1}\right)$ for the three water masses: surface water, WW, and UCDW for the IN and OUT-patch stations. In cases where no standard deviation is given, there was only one sample analyzed in WW. See Table 2 for WW standard errors.

\begin{tabular}{|c|c|c|c|c|}
\hline Station & & $\begin{array}{l}\text { Surface Water } \\
0-50 \mathrm{~m}\end{array}$ & $\begin{array}{c}\mathrm{WW} \\
\mathrm{T}^{\circ} \mathrm{C} \text { min depth }\end{array}$ & $\begin{array}{l}\text { UCDW } \\
500-1000 \mathrm{~m}\end{array}$ \\
\hline \multicolumn{5}{|l|}{ IN-patch } \\
\hline \multirow[t]{5}{*}{42417 (day -1) } & & & $250 \mathrm{~m}$ & \\
\hline & $\delta^{30} \mathrm{Si}_{\mathrm{DSi}}$ & $2.23 \pm 0.15$ & 1.65 & $1.51 \pm 0.07$ \\
\hline & $\mathrm{DSi}$ & $18.9 \pm 0.0$ & 40.9 & $80.3 \pm 4.8$ \\
\hline & $\delta^{30} \mathrm{Si}_{\mathrm{BSi}}$ & $0.91 \pm 0.13$ & & \\
\hline & $\mathrm{BSi}$ & $2.2 \pm 0.2$ & & \\
\hline \multirow[t]{5}{*}{50816 (day 10) } & & & $200 \mathrm{~m}$ & \\
\hline & $\delta^{30} \mathrm{Si}_{\mathrm{DSi}}$ & $2.42 \pm 0.01$ & 1.51 & $1.28 \pm 0.09$ \\
\hline & DSi & $15.9 \pm 0.0$ & 33.4 & $78.7 \pm 4.8$ \\
\hline & $\delta^{30} \mathrm{Si}_{\mathrm{BSi}}$ & $0.92 \pm 0.06$ & & \\
\hline & $\mathrm{BSi}$ & $3.2 \pm 0.1$ & & \\
\hline \multirow[t]{5}{*}{5438 (day 21) } & & & $250 \mathrm{~m}$ & \\
\hline & $\delta^{30} \mathrm{Si}_{\mathrm{DSi}}$ & $2.47 \pm 0.09$ & 1.38 & $1.23 \pm 0.09$ \\
\hline & $\mathrm{DSi}$ & $12.4 \pm 0.1$ & 37.3 & $71.2 \pm 2.4$ \\
\hline & $\delta^{30} \mathrm{Si}_{\mathrm{BSi}}$ & $1.13 \pm 0.09$ & & \\
\hline & $\mathrm{BSi}$ & $3.3 \pm 0.9$ & & \\
\hline \multirow[t]{3}{*}{54463 (day 23) } & & & $200-300 \mathrm{~m}$ & \\
\hline & $\delta^{30} \mathrm{Si}_{\mathrm{DSi}}$ & $3.16 \pm 0.27$ & $1.84 \pm 0.05$ & $1.64 \pm 0.20$ \\
\hline & DSi & $10.8 \pm 0.01$ & $37.4 \pm 10.3$ & $77.3 \pm 6.0$ \\
\hline \multirow[t]{5}{*}{55310 (day 28) } & & & $250 \mathrm{~m}$ & \\
\hline & $\delta^{30} \mathrm{Si}_{\mathrm{DSi}}$ & $2.67 \pm 0.04$ & 1.70 & $1.33 \pm 0.05$ \\
\hline & DSi & $9.3 \pm 0.1$ & 39.7 & $77.1 \pm 2.7$ \\
\hline & $\delta^{30} \mathrm{Si}_{\mathrm{BSi}}$ & $1.24 \pm 0.04$ & & \\
\hline & $\mathrm{BSi}$ & $5.6 \pm 0.2$ & & \\
\hline \multirow[t]{5}{*}{59312 (day 36) } & & & $250 \mathrm{~m}$ & \\
\hline & $\delta^{30} \mathrm{Si}_{\mathrm{DSi}}$ & $2.83 \pm 0.15$ & 1.40 & $1.21 \pm 0.13$ \\
\hline & DSi & 7.5 & 35.8 & $74.2 \pm 5.8$ \\
\hline & $\delta^{30} \mathrm{Si}_{\mathrm{BSi}}$ & $1.61 \pm 0.23$ & & \\
\hline & $\mathrm{BSi}$ & 5.7 & & \\
\hline \multicolumn{5}{|l|}{ OUT-patch } \\
\hline \multirow[t]{3}{*}{48412 (day 7) } & & & $150-300 \mathrm{~m}$ & \\
\hline & $\delta^{30} \mathrm{Si}_{\mathrm{DSi}}$ & $2.65 \pm 0.00$ & $1.64 \pm 0.08$ & $1.33 \pm 0.14$ \\
\hline & $\mathrm{DSi}$ & $9.1 \pm 0.4$ & $33.2 \pm 12.8$ & $70.6 \pm 7.0$ \\
\hline \multirow{5}{*}{50913 (day 11) } & & & $250 \mathrm{~m}$ & \\
\hline & $\delta^{30} \mathrm{Si}_{\mathrm{DSi}}$ & $2.58 \pm 0.09$ & - & - \\
\hline & DSi & $13.8 \pm 0.0$ & 35.5 & $73.3 \pm 6.0$ \\
\hline & $\delta^{30} \mathrm{Si}_{\mathrm{BSi}}$ & $1.04 \pm 0.15$ & & \\
\hline & $\mathrm{BSi}$ & $3.6 \pm 0.7$ & & \\
\hline \multirow[t]{5}{*}{54614 (day 25) } & & & $250 \mathrm{~m}$ & \\
\hline & $\delta^{30} \mathrm{Si}_{\mathrm{DSi}}$ & $2.53 \pm 0.01$ & - & - \\
\hline & DSi & $8.4 \pm 0.0$ & 38.8 & $75.5 \pm 3.5$ \\
\hline & $\delta^{30} \mathrm{Si}_{\mathrm{BSi}}$ & $1.65 \pm 0.12$ & & \\
\hline & $\mathrm{BSi}$ & $1.6 \pm 0.1$ & & \\
\hline \multirow{5}{*}{58710 (day 34) } & & & $250 \mathrm{~m}$ & \\
\hline & $\delta^{30} \mathrm{Si}_{\mathrm{DSi}}$ & $2.76 \pm 0.34$ & 1.74 & $1.21 \pm 0.09$ \\
\hline & DSi & $9.8 \pm 0.1$ & 40.5 & $76.9 \pm 5.7$ \\
\hline & $\delta^{30} \mathrm{Si}_{\mathrm{BSi}}$ & $1.68 \pm 0.01$ & & \\
\hline & $\mathrm{BSi}$ & $1.4 \pm 0.0$ & & \\
\hline \multirow[t]{3}{*}{ Averages } & & & WW IN+OUT & UCDW IN+OUT \\
\hline & $\delta^{30} \mathrm{Si}_{\mathrm{DSi}}$ & & $1.61 \pm 0.16$ & $1.34 \pm 0.16$ \\
\hline & DSi & & $37.3 \pm 2.8$ & $75.5 \pm 3.2$ \\
\hline
\end{tabular}

other values (Table 2; Fig. 3A). Unfortunately BSi was not sampled at this station, preventing us from shedding light on the reason for this exceptionally high $\delta^{30} \mathrm{Si}_{\mathrm{DSi}}$ value.
Diatoms were also dominant in OUT-patch waters (Hoffmann et al., 2006), but the evolution of their DSi and $\mathrm{BSi}$ concentrations cannot be explained alone with biological consumption of DSi (Fig. 3B). Three different 


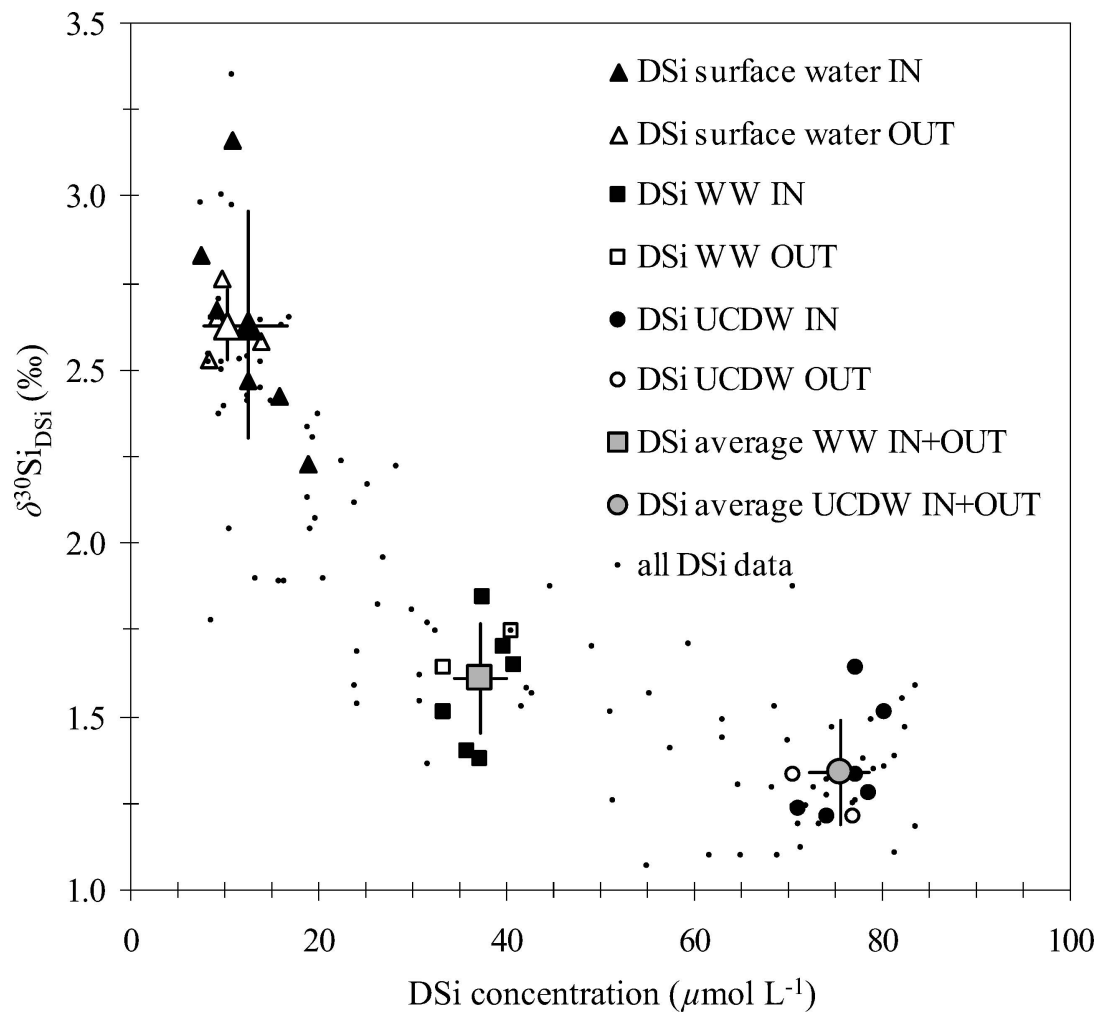

Fig. 2. $\delta^{30} \mathrm{Si}_{\mathrm{DSi}}$ vs. DSi dataset obtained from the EIFEX experiment (Table 2). DSi surface water (small triangles), winter water (WW, small squares), and upper circumpolar deep water (UCDW, small circles) represent the water mass averages for each sampling event (Table 3). For clarity, standard deviations of station's averages are not shown here; they are available in Table 3. For the duration of the experiment (37 d), DSi average surface water (separate averages for IN- and OUT-patch, represented by the large black triangle and the large white triangle, respectively), average $\mathrm{WW}_{\mathrm{IN}+\mathrm{OUT}}$ (large gray square) and average UCDW IN+OUT (large grey circle) show the observed variability. Error bars represent the average standard deviation $\left(2 \sigma_{\mathrm{SD}}\right)$.

explanations are possible for the observed $\delta^{30} \mathrm{Si}_{\mathrm{BSi}}$ increase and concomitant [BSi] decrease. A preferential export of older and thus isotopically lighter diatoms might have taken place, thereby increasing $\delta^{30} \mathrm{Si}_{\mathrm{BSi}}$ of the remaining BSi pool while simultaneously decreasing BSi contents. Note that Cardinal et al. (2007) suggested selective diatom export from the Southern Ocean mixed layer based on $\mathrm{Si}$ isotopic signatures of different diatoms' size fractions. Dissolution of $\mathrm{BSi}$, whereby light $\mathrm{Si}$ isotopes are preferentially released, could also enrich the remnant BSi pool in heavy isotopes (Demarest et al. 2009). The latter process is consistent with a $\delta^{30} \mathrm{Si}_{\mathrm{BSi}}$ increase accompanied by a $\mathrm{BSi}$ decrease and would not significantly affect the isotopic composition and magnitude of the much larger DSi pool (DSi:BSi ratio is $\sim 10$ ). However, since the sampling strategy for OUT-patch casts did not warrant sampling of the same water masses throughout the experiment (Hoffmann et al. 2006), the observed variability of BSi and $\delta^{30} \mathrm{Si}_{\mathrm{BSi}}$ might just as well reflect heterogeneity in spatial gradients within the eddy. Therefore, a more detailed interpretation of our results for OUT-patch samples is not possible.

Fractionation factor for the artificial iron fertilized patch (IN-patch)-To describe the variation of $\delta^{30} \mathrm{Si}_{\mathrm{DSi}}$ and $\delta^{30} \mathrm{Si}_{\mathrm{BSi}}$ over the course of a $\mathrm{Si}$-consumption process, two ideal conceptual models can be used: the closed system and the open flow-through system model (Fry 2006). Sigman et al. (1999) described such models in detail for nitrate, and these have been applied by Cardinal et al. (2005), Varela et al. (2004), and Fripiat et al. (in press) for silicon in the modern Southern Ocean. The closed system model assumes that the surface silicic acid pool is not replenished from an external source during the course of the seasonal nutrient consumption. In this case the uptake process can be described in terms of a Rayleigh fractionation model (Mariotti et al. 1981), where isotopic composition of the instantaneous $\mathrm{BSi}$ produced $\left(\delta^{30} \mathrm{Si}_{\mathrm{BS}}\right.$ inst) differs from the accumulated $\mathrm{BSi}\left(\delta^{30} \mathrm{Si}_{\mathrm{BSi}}\right.$ acc $)$ according to the following equations:

$$
\begin{aligned}
\delta^{30} \mathrm{Si}_{\mathrm{DSi}} & =\delta^{30} \mathrm{Si}_{\mathrm{DSi} \text { source }}+\varepsilon \ln f \\
\delta^{30} \mathrm{Si}_{\mathrm{BSi}} \text { inst } & =\delta^{30} \mathrm{Si}_{\mathrm{DSi}}+\varepsilon \\
\delta^{30} \mathrm{Si}_{\mathrm{BSi} \text { acc }} & =\delta^{30} \mathrm{Si}_{\mathrm{DSi} \text { source }}-\varepsilon[f \ln f /(1-f)]
\end{aligned}
$$

The open flow-through system model (also referred to as steady state or open fractionation model) assumes a 

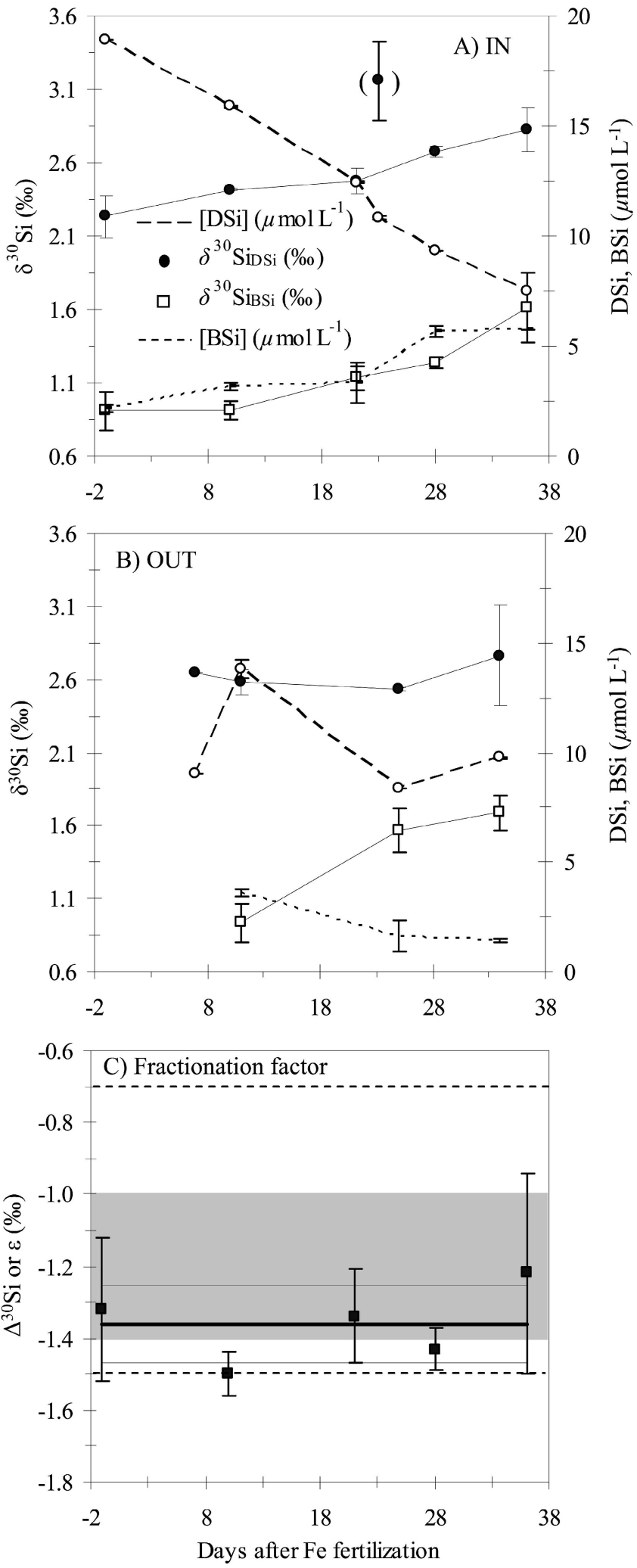

Fig. 3. Temporal variations of $\delta^{30} \mathrm{Si}_{\mathrm{DSi}}, \delta^{30} \mathrm{Si}_{\mathrm{BSi}}, \mathrm{BSi}$, and DSi concentrations in the surface layer (upper $50 \mathrm{~m}$ ) (A) IN-patch and (B) OUT-patch. Error bars $\left(2 \sigma_{\mathrm{SD}}\right)$ represent the average standard deviation for surface samples at each station. (A) The point between brackets represents Sta. 54463 and was not considered part of the temporal trend (see text for further details). balance between the input (DSi supply) and the output (residual DSi and BSi formed).

$$
\begin{aligned}
\delta^{30} \mathrm{Si}_{\mathrm{DSi}} & =\delta^{30} \mathrm{Si}_{\mathrm{DSi}} \text { initial }-\varepsilon(1-f) \\
\delta^{30} \mathrm{Si}_{\mathrm{BSi}} & =\delta^{30} \mathrm{Si}_{\mathrm{DSi} \text { source }}+\varepsilon f
\end{aligned}
$$

Eq. 2 is also applicable to the steady-state model since in an open system the product (BSi) has a homogeneous isotopic composition always in equilibrium with the substrate (DSi). In the above equations, $f$ is the fraction of DSi remaining in the reservoir $\left(f=[\mathrm{DSi}]_{\text {observed }} /[\mathrm{DSi}]_{\text {source }}\right)$ and $\delta^{30} \mathrm{Si}_{\mathrm{DSi}}$ source is the initial isotopic signature of the DSi source. It is likely that natural environments rather obey a hybrid mode between true closed and open-flow modes, with predominance of either one mode depending on the uptake: supply ratio (Fry 2006).

Since it is not known a priori whether the system strictly follows one of the ideal models described above, the difference between the isotopic compositions of substrate and product is usually named the "apparent fractionation factor" or $\Delta^{30} \mathrm{Si}=\delta^{30} \mathrm{Si}_{\mathrm{BSi}}$ measured $-\delta^{30} \mathrm{Si} \mathrm{DSi}_{\text {measured. }}$ Although the $\Delta^{30} \mathrm{Si}$ approach has been shown to be sometimes biased by $\delta^{30} \mathrm{Si}_{\mathrm{DSi}}$ and $\delta^{30} \mathrm{Si}_{\mathrm{BSi}}$ signatures resulting from asynchronous processes (Cardinal et al. 2007), this is not likely to be the case for IN-patch EIFEX since both DSi and BSi reservoirs are followed simultaneously over a $37-d$ period and exhibit consistent patterns (Figs. 1, 3A). In contrast to Eqs. 1, 3, 4, 5, $\Delta^{30} \mathrm{Si}$ presents the advantage of using both the $\delta^{30} \mathrm{Si}_{\mathrm{BSi}}$ and $\delta^{30} \mathrm{Si}_{\mathrm{DSi}}$ datasets without the need to choose between a closed and an open mode of operation and to know the Si source. It also integrates the potential bias due to isotopic fractionation during dissolution (Demarest et al. 2009). We observe that the average $\Delta^{30} \mathrm{Si}$ remains constant over the duration of the experiment at $-1.36 \% \pm \pm 0.11 \%$ with no significant temporal trend ( $p=0.49$; Fig. 3C).

Recently, Fripiat et al. (in press) proposed a refined estimate of the fractionation factor for the ACC as based on a compilation of data estimated from seasonal variation in $\delta^{30} \mathrm{Si}_{\mathrm{DSi}}$ (Varela et al. 2004; Cardinal et al. 2005; Fripiat et al. in press). Note that only $\delta^{30} \mathrm{Si}_{\mathrm{DSi}}$ data for irondepleted ACC waters (Measures and Vink 2001; Sedwick et al. 2008; Chever et al. 2010) were used in Fripiat et al. (in press). This refined estimate $(\varepsilon=-1.2 \% 0 \pm 0.2 \%)$ is not significantly different from results based on in vitro incubation experiments using temperate marine diatoms $\left(\varepsilon=-1.1 \%\right.$ $\pm 0.4 \%$; De La Rocha et al., 1997). Our $\Delta^{30} \mathrm{Si}$ value of $-1.36 \%$ $\pm 0.11 \%$ fits rather well within the refined Southern Ocean estimates and therefore is likely to

(C) Temporal variation of EIFEX $\Delta^{30} \mathrm{Si}\left(\delta^{30} \mathrm{Si}_{\mathrm{BSi}}-\delta^{30} \mathrm{Si}_{\mathrm{DSi}}\right)$ calculated at each IN-patch station and the resulting average $\Delta^{30} \mathrm{Si}$ (thick plain line) $\pm 1 \sigma_{\mathrm{SD}}$ (thin plain lines). Indent lines represent the range of $\varepsilon=-1.1 \% \pm \pm 0.4 \%$ measured on incubations for temperate diatoms (De La Rocha et al. 1997). Flat gray shading area represents the refined $\varepsilon$ estimate $=-1.2 \%$ $\pm 0.2 \%$ in Southern Ocean Fe-depleted waters (Fripiat et al. in press). 
represent the true fractionation factor (Fig. 3C). The constancy of $\Delta^{30} \mathrm{Si}$ throughout the EIFEX experiment and the agreement of fractionation factors between fertilized and natural systems also suggest that $\mathrm{Si}$ isotopic fractionation is not significantly affected by Fe availability. Since $\delta^{30} \mathrm{Si}_{\mathrm{BSi}}$ might be more sensitive to bias than $\delta^{30} \mathrm{Si}_{\mathrm{DSi}}$ (Varela et al. 2004; Cardinal et al. 2007), we can estimate $\varepsilon$ using only $\delta^{30} \mathrm{Si}_{\mathrm{DSi}} \mathrm{IN}$-patch data. Applying the Rayleigh model (Eq. 1), we estimate $\varepsilon=-0.60 \% \pm 0.19 \%$; applying the open flow-through model (Eq. 4) and assuming WW IN+OUT average (Table 3) as the source for initial DSi content yields $\varepsilon=-1.51 \% 0 \pm 0.34 \%$. The average $\Delta^{30} \mathrm{Si}$ of $-1.36 \% \pm 0.11 \%$ is in between the outcome for open and closed models, suggesting the system operates partly as an open and closed one, as already raised in Varela et al. (2004). Nevertheless we note that for EIFEX, $\Delta^{30} \mathrm{Si}$ is closer to the open system $\varepsilon$ estimate. When removing station 544 63 , day 23 (which was not sampled for $\delta^{30} \mathrm{Si}_{\mathrm{BSi}}$ and which had the largest $\delta^{30} \mathrm{Si}_{\mathrm{DSi}}$ value) the calculated $\varepsilon$ is then $-1.38 \%$ o $\pm .11 \%$ for open systems, which is very similar to the $\Delta^{30} \mathrm{Si}$ value $(-1.36 \% \pm 0.11 \%$ ). This provides further support for an open system mode operating dominantly during EIFEX.

Silicon source and supply to the mixed layer-Since on the basis of constant $\Delta^{30} \mathrm{Si}$ we are not able to differentiate between open or closed system functioning, we will reconstruct the evolution of the EIFEX IN-patch surface water $\mathrm{BSi}$ and $\mathrm{DSi}$ isotopic signals using different hypotheses, in order to identify $\mathrm{Si}$ source and mode of $\mathrm{Si}$ supply.

Taking $\Delta^{30} \mathrm{Si}=-1.36 \%$ o $\pm 0.11 \%$ as the fractionation factor, we reconstruct temporal $\delta^{30} \mathrm{Si}_{\mathrm{BSi}}$ and $\delta^{30} \mathrm{Si}_{\mathrm{DSi}}$ variations as a function of $f$ (the fraction of DSi remaining in the IN-patch surface water along the experiment) for different initial conditions, applying both the closed and open model approaches (Fig. 4). Conceptually, the open model represents an equilibrium condition, and therefore no temporal variation of substrate and product is expected. In order to apply the open system approach we need to consider the five successive sampling events along the experiment as a succession of steady state conditions. Parameters to be defined are thus the Si source characteristics: [DSi] source and $\delta^{30} \mathrm{Si}_{\mathrm{DSi}}$ source. Following previous studies we will assume that WW represents the source water for the open system model (Altabet and François 2001; Cardinal et al. 2005; Fripiat et al. in press). Since there was little variation of WW characteristics between IN- and OUT-patch over the duration of the study (see above), the following average $\mathrm{WW}_{\mathrm{IN}+\mathrm{OUT}}$ values were considered and applied to Eqs. 4, 5 (Table 3; Fig. 4A,B): $\delta^{30} \mathrm{Si}_{\mathrm{DSi}}=1.61 \%$ $\pm 0.16 \%$ and $[\mathrm{DSi}]=37.3 \pm 2.8 \mu \mathrm{mol} \mathrm{L}-1$.

For the Rayleigh model we use Eq. 1 to calculate $\delta^{30} \mathrm{Si}_{\mathrm{DSi}}$ and Eqs. 2, 3 to calculate $\delta^{30} \mathrm{Si}_{\mathrm{BSi}}$ inst and $\delta^{30} \mathrm{Si}_{\mathrm{BSi}}$ acc, respectively. We tested the suitability of $\mathrm{WW}_{\mathrm{IN}+\mathrm{OUT}}$ $\left(\delta^{30} \mathrm{Si}_{\mathrm{DSi}}=1.61 \% 0 \pm 0.16 \%\right.$ and $[\mathrm{DSi}]=37.3 \pm$ $2.8 \mu \mathrm{mol} \mathrm{L}-1$; Table 3; Fig. 4C,D) and IN-patch surface water conditions at initial time (day $-1, \delta^{30} \mathrm{Si}_{\mathrm{DSi}}=2.23 \%$ 土 $0.15 \%$ and $[\mathrm{DSi}]=18.9 \mu \mathrm{mol} \mathrm{L}-1$; Table 3 ; Fig. $4 \mathrm{E}, \mathrm{F})$ as prefertilization initial conditions. The latter initial condi- tions are likely to yield the best reconstruction of the EIFEX system. Indeed, they account for some mixing with subsurface waters that most likely took place during the period between the onset of the season and the start of the fertilization, modifying the "true" initial conditions (i.e., before the start of natural bloom) as represented by WW. Figure 4C,E clearly shows that the Rayleigh closed system model for $\delta^{30} \mathrm{Si}_{\mathrm{DSi}}$ systematically overestimates the observed isotopic compositions. The assumption that no mixing with subsurface waters took place over the entire duration of the growth season can be tested using the $\mathrm{WW}_{\mathrm{IN}+\mathrm{OUT}} \delta^{30} \mathrm{Si}_{\mathrm{DSi}}$ conditions as the initial ones (Fig. 4C,D). Indeed, the mismatch is even worse both for $\delta^{30} \mathrm{Si}_{\mathrm{DSi}}$ and $\delta^{30} \mathrm{Si}_{\mathrm{BSi}}$ than when using day -1 surface water conditions (Fig. 4E,F). In contrast, the Rayleigh model results for accumulated $\delta^{30} \mathrm{Si}_{\mathrm{BSi}}$ based on day -1 surface water initial DSi conditions (Fig. 4F) reproduce rather well the observed $\delta^{30} \mathrm{Si}_{\mathrm{BSi}}$ values. Such agreement can be attributed to the continuous biological $\mathrm{Si}$ uptake by diatoms over the duration of the EIFEX experiment as reported also by Hoffmann et al. (2006). Since the Rayleigh fractionation model does not reproduce the observed evolution of the $\delta^{30} \mathrm{Si}_{\mathrm{DSi}}$, it is unlikely that a closed system applies here.

In contrast, the open model with WW as the Si source reproduces well the observed IN-patch surface water for both $\delta^{30} \mathrm{Si}_{\mathrm{BSi}}$ and $\delta^{30} \mathrm{Si}_{\mathrm{DSi}}$ values (Fig. $4 \mathrm{~A}, \mathrm{~B}$ ). While it might appear that the open model slightly underestimates $\delta^{30} \mathrm{Si}_{\mathrm{DSi}}$ (Fig. 4A), we note that the standard deviations of the $\delta^{30} \mathrm{Si}_{\mathrm{DSi}}$ values overlap the boundaries of the open model. As previously stressed, model results suggest that the Si biogeochemistry in the EIFEX eddy obeyed a hybrid mode of operation. The open system mode, however, appears to have dominated the Si cycle during EIFEX, since it successfully reproduces both the DSi and BSi isotopic signatures. This outcome highlights the significance of vertical Si supply from WW to the surface waters.

Cyclonic eddies can produce upwelling, which has been observed to locally increase productivity by the upward advection of nutrients into the euphotic zone, a process that has been called eddy pumping (McGillicudy et al. 1998). However, based on the analysis of both hydrographic and microstructure data, Cisewski et al. (2008) found no indications for upwelling within the eddy. Moreover, if eddy pumping was involved in the Si supply, we should observe a shoaling of isopycnals and isotherms in the top $500 \mathrm{~m}$ of the water column of the eddy. The vertical distribution of temperature and density along the crosseddy section does not show such a feature. Therefore, vertical mixing and vertical diffusion are the major processes involved in the vertical Si supply from WW.

Using the upper thermocline vertical diffusivity $K_{\mathrm{T}}$ estimate reported for EIFEX $\left(7.06 \times 10^{-4} \mathrm{~m}^{2} \mathrm{~s}^{-1}\right.$; Cisewski et al. 2008) we calculate the vertical Si supply from WW to the surface layer IN-patch as follows:

$$
\begin{aligned}
& \text { Vertical Si supply }= \\
& \qquad K_{\mathrm{T}}\left([\mathrm{DSi}]_{\mathrm{WW} \text { IN }+ \text { OUT }}-[\mathrm{DSi}]_{\mathrm{IN}-\text { patch SW } i}\right) / Z
\end{aligned}
$$

where $K_{\mathrm{T}}$ is the vertical diffusivity in the upper thermocline, 

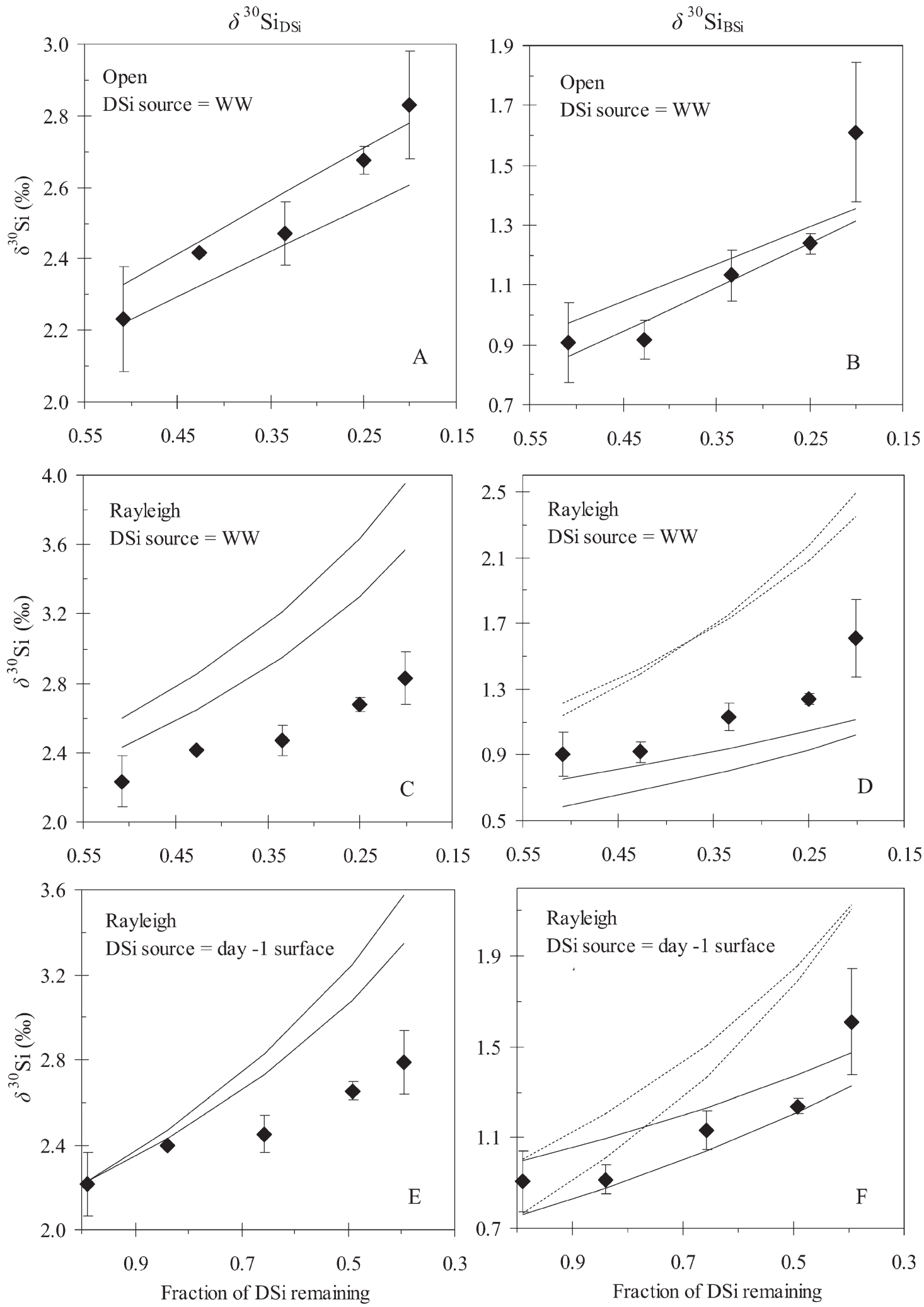

Fig. 4. $\delta^{30} \mathrm{Si}_{\mathrm{DSi}}$ and $\delta^{30} \mathrm{Si}_{\mathrm{BSi}}$ variations in the IN-patch surface layer (upper $50 \mathrm{~m}$ ) vs. fraction of DSi remaining in the reservoir (see text for details). Observations $=$ filled diamonds. Error bars $\left( \pm 1 \sigma_{\mathrm{SD}}\right)$ on $\delta^{30} \mathrm{Si}_{\mathrm{DSi}}$ and $\delta^{30} \mathrm{Si}_{\mathrm{BSi}}$ data represent the average standard deviation for each station in the surface layer. Reconstructed trends (lines) have been calculated using the lowest $(-1.36-0.11=$ $-1.47 \%$ ) and highest $(-1.36+0.11=-1.25 \%$ ) estimates of EIFEX fractionation factor. (A, B) Open and (C-F) closed fractionation models. (D, F) solid lines represent $\delta^{30} \mathrm{Si}_{\mathrm{BSi}}$ acc. (Eq. 3), dashed lines represent $\delta^{30} \mathrm{Si}_{\mathrm{BSi}}$ inst (Eq. 2). Sta. 54463 (day 23) is not considered for these estimations (see text for details). 
$\mathrm{Z}$ is the layer thickness (WW depth - middle of the surface water layer $=250-25=225 \mathrm{~m})$; [DSi] ww IN+OUT is the WW DSi concentration $\left(37.3 \pm 2.8 \mu \mathrm{mol} \mathrm{L}^{-1}\right)$; and [DSi] IN-patch $\mathrm{SW}_{i}$ is the average DSi concentration in the surface water IN-patch at each sampling event $i$ (Table 3). We calculate a vertical DSi supply over the duration of the EIFEX experiment of $249 \pm 43 \mathrm{mmol} \mathrm{Si} \mathrm{m}{ }^{-2}$ (37 d), equivalent to an average daily DSi supply of $6.7 \pm 1.2 \mathrm{mmol}$ $\mathrm{Si} \mathrm{m}^{-2} \mathrm{~d}^{-1}$ (the uncertainty on these flux estimates represents the propagated error).

Silicon uptake and export during EIFEX-DSi concentration of IN-patch surface water decreased by

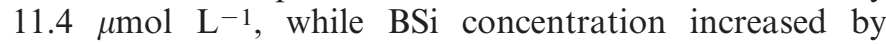
$3.5 \mu \mathrm{mol} \mathrm{L}-1$ over $37 \mathrm{~d}$. Integrated over the upper $50 \mathrm{~m}$ this corresponds to a DSi decline of $570 \pm 53 \mathrm{mmol} \mathrm{Si} \mathrm{m}^{-2}$ and a BSi increase of $175 \pm 31 \mathrm{mmol} \mathrm{Si} \mathrm{m}^{-2}$. Comparing the total DSi consumption (i.e., DSi decrease + DSi-supply $=570+249=819 \pm 68 \mathrm{mmol} \mathrm{DSi} \mathrm{m}^{-2}$, equivalent to 22.1 $\pm 1.8 \mathrm{mmol} \mathrm{DSi} \mathrm{m}^{-2} \mathrm{~d}^{-1}$ ) and the surface water BSi increase over the $37 \mathrm{~d}\left(175 \pm 31 \mathrm{mmol} \mathrm{BSi} \mathrm{m}^{-2}\right)$, we obtain a deficit in the mass balance of $644 \pm 61 \mathrm{mmol} \mathrm{BSi} \mathrm{m}^{-2}$ $\left(17.4 \pm 1.7 \mathrm{mmol} \mathrm{BSi} \mathrm{m}^{-2} \mathrm{~d}^{-1}\right)$.

Jacquet et al. (2008) report a C export flux of $872 \pm$ $60 \mathrm{mmol} \mathrm{C} \mathrm{m}^{-2}$ from the upper $150 \mathrm{~m}$ over the $37 \mathrm{~d}$ of the EIFEX experiment, and such export to deeper layers could also account for the missing $\mathrm{BSi}$. The $\mathrm{BSi}$ : $\mathrm{POC}$ atom ratio of the sinking particles should then be given by the ratio of the missing BSi over the $\mathrm{C}$ export, that is, $644: 872=0.7 \pm$ 0.1 . For mixed layer microphytoplankton $(>20 \mu \mathrm{m})$ Hoffmann et al. (2007) report that the $\mathrm{BSi}: \mathrm{POC}$ ratio shifted from 0.3 during the first $15 \mathrm{~d}$ of the EIFEX experiment to $0.6 \pm 0.1$ on from day 20 , while for picophytoplankton and nanophytoplankton $(<20 \mu \mathrm{m})$ the increase in BSi : POC ratio was from 0.15 to 0.45 . Since such values for microphytoplankton are quite close to the BSi : POC value calculated here, and since some increase of the BSi:POC ratio with depth has been documented (Quéguiner et al. 1997; Ragueneau et al. 2006), our results support the view that the larger diatoms were responsible for most of the export observed for the second half period of EIFEX. Overall, our data are in good accordance with the observations by Hoffmann et al. (2006, 2007) and Jacquet et al. (2008) and provide evidence for an open mode of operation of the IN-patch system where the DSi supplied from underlying WW represents some $30 \%$ of total DSi consumed. This consumed DSi is in turn largely exported as BSi to deeper layers.

The open model approach allows estimating the fraction $f$ of initial DSi consumed since the onset of the growth season $\left(f=[\mathrm{DSi}]_{\text {observed }} /[\mathrm{DSi}]\right.$ source; with source $=$ $\mathrm{WW}_{\mathrm{IN}+\mathrm{OUT}}$ ) as follows (see also Fig. 4A,B):

Fraction of initial DSi consumed $(\%)=$

$$
\left(1-f_{\text {day }-1}\right) \times 100
$$

Where $f_{\text {day }-1}=0.51 \pm 0.04$, meaning that at day $-1,49 \%$ $\pm 4 \%$ of the original prebloom DSi reservoir was already consumed (Fig. 4A,B), in agreement with the indications that a bloom had occurred in the area before the EIFEX experiment started (Hoffmann et al. 2006; Jacquet et al. 2008). The Fe fertilization resulted in an additional depletion of the initial DSi reservoir by $31 \% \pm 4 \%\left(\left(f_{\text {day }-1}-f_{\text {day } 37}\right)\right.$ $\times 100$, where $f_{\text {day } 37}=0.20 \pm 0.02$; Fig. 4A,B). Thus, the total relative use of DSi since the onset of the season is $80 \%$ $\pm 4 \%$.

Toward the end of the experiment (day 28; Fig. 3A), INpatch $\delta^{30} \mathrm{Si}_{\mathrm{DSi}}$ and $\delta^{30} \mathrm{Si}_{\mathrm{BSi}}$ continued to increase toward heavier signatures, contrasting with the fact that $\mathrm{BSi}$ concentrations leveled off (Fig. 3A), corroborating the observation by Hoffmann et al. (2006) that diatom abundance during EIFEX started to decrease from day 26. A situation where Si uptake continues while cells number remains stable or decreases may be explained by an increase in relative abundance of more heavily silicified diatom frustules. This possibility is also supported by an increase of the BSi:POC ratio in the surface layer (Hoffmann et al. 2006, 2007), a feature that seems characteristic of $\mathrm{Fe}$ enrichments in Si-replete conditions (Marchetti et al. 2010).

Jacquet et al. (2008) report a massive C export to deeper layer at the end of the experiment, and it appears likely that this export concerned mainly the older generations of diatoms, which would bear the lightest $\delta^{30} \mathrm{Si}_{\mathrm{BSi}}$. Moreover, preferential release of light isotopes during BSi dissolution would also result in a heavier remnant BSi pool (Demarest et al. 2009). However, since the increase of $\delta^{30} \mathrm{Si}_{\mathrm{BSi}}$ does not seem to be associated with changes in the rates of DSi decrease and $\delta^{30} \mathrm{Si}_{\mathrm{DSi}}$ increase (i.e., no change of slope in Fig. 3A), we favor export scenario combined with uptake to explain the observed isotopic enrichment of BSi toward the end of EIFEX. Indeed, although BSi dissolution could not be ruled out, it appears to have a limited effect both on $\mathrm{Si}$ concentrations and isotopic signature.

Comparison with previous BSi production and export estimations in the polar frontal zone (PFZ)-For the AESOPS study (summer 1997-1998; PFZ, Pacific sector) Brzezinski et al. (2001) report a high BSi biomass with a high production rate, reaching up to $24.8 \mathrm{mmol} \mathrm{Si} \mathrm{m}^{-2} \mathrm{~d}^{-1}$. This maximum value agrees well with our BSi production estimate of $22.1 \pm 1.8 \mathrm{mmol} \mathrm{Si} \mathrm{m}^{-2} \mathrm{~d}^{-1}$. Our estimate fits the lower range of high production rates (between 29.6 and $60.7 \mathrm{mmol}$ Si $\mathrm{m}^{-2} \mathrm{~d}^{-1}$ ) reported by Quéguiner and Brzezinski (2002) for natural systems south of the PFZ during spring.

The average daily BSi export during EIFEX is $17.4 \pm$ $1.7 \mathrm{mmol} \mathrm{Si} \mathrm{m} \mathrm{m}^{-2} \mathrm{~d}^{-1}$ while for AESOPS, Buesseler et al. (2001) report a smaller BSi export (derived from total $234 \mathrm{Th}$ fluxes) ranging between 1.4 and $11 \mathrm{mmol} \mathrm{Si} \mathrm{m} \mathrm{m}^{-2} \mathrm{~d}^{-1}$. During the Southern Ocean iron release experiment no significant increase of export was observed (Trull et al. 2001), probably as a result of the too short duration of the survey (13 d). Several system-specific factors (algal $\mathrm{Fe}$ uptake, food web structure and grazing activity, particle properties and transformations including sinking rate or scavenging) may act on the efficiency of export induced by Fe addition (Boyd et al. 2007), possibly explaining this variability in BSi export between different FeAX.

Using an inverse model approach, Jin et al. (2006) estimated an export of opal ranging generally between 1 
and $5 \mathrm{~mol} \mathrm{Si} \mathrm{m}{ }^{-2} \mathrm{yr}^{-1}$ (with a maximum around $60^{\circ} \mathrm{S}$ ) and occasionally above $7 \mathrm{~mol} \mathrm{Si} \mathrm{m} \mathrm{m}^{-2} \mathrm{yr}^{-1}$ in the Southern Ocean. Assuming a productive period of 5 months per year (Trull et al. 2001), this estimation yields to an opal export (BSi) ranging between 7 and $33 \mathrm{mmol} \mathrm{Si} \mathrm{m} \mathrm{m}^{-2} \mathrm{~d}^{-1}$ (occasionally above $45 \mathrm{~mol} \mathrm{Si} \mathrm{m} \mathrm{m}^{-2} \mathrm{yr}^{-1}$ ). The EIFEX BSi export estimate fits with these Jin et al. (2006) estimates. Overall we conclude that BSi export induced by Fe fertilization during EIFEX was of the same order of magnitude as $\mathrm{BSi}$ export observed for the natural Southern Ocean, a feature already stressed in Jacquet et al. (2008).

Our results provide useful information on the effect of $\mathrm{FeAX}$ on Si cycle and confirm the value of the $\mathrm{Si}$ isotopes proxy to estimate $\mathrm{Si}$ fluxes and identify $\mathrm{Si}$ sources in wellconstrained oceanic systems. Our observation that the EIFEX fertilized patch behaved more as an open system in terms of Si cycle also has implications for other nutrients and should be considered for further calculation on nutrient budgets.

\section{Acknowledgments}

We thank the captain and crew of R/V Polarstern, the chief scientist V. Smetacek, and cochief scientist V. Strass (Alfred Wegener Institute [AWI]) for assistance during work at sea. We are grateful to N. Dahkani, L. Monin, H. Hughes (RMCA), J. de Jong, and N. Mattielli (ULB) for their technical and scientific support, and A. Webb for on-board nutrient analyses. We thank David S. Baston (Vrije Universiteit Brussel [VUB]) for English proofreading of a first version of this manuscript. This research was supported by the European Network of Excellence for Ocean Ecosystems Analysis through a Ph.D. grant to A.-J.C. (EUROCEANS FP6 contract 511106) and the Federal Belgian Science Policy Office (BELSPO) under the Science for Sustainable Development (SDD) program (Integrated Study of Southern Ocean Biogeochemistry and Climate Interaction in the Anthropocène BELCANTO contracts EV/37/7C, EV/03/7A, SD/CA/ 03A). L.A. thanks the Fonds National de la Recherche Scientifique (FNRS; contract Fond de la Recherche Fondamentale Collective FRFC number 2.4.512.00F) for funding the $\mathrm{Nu}$ Plasma MC-ICP-MS. Two anonymous reviewers are warmly thanked for their constructive comments, which greatly improved the manuscript.

\section{References}

Abraham, K., S. Opfergelt, F. Fripiat, A.-J. Cavagna, J. T. M. De Jong, S. Foley, L. André, and D. Cardinal. 2008. $\delta^{30} \mathrm{Si}$ and $\delta^{29} \mathrm{Si}$ determination on BHVO-1 and BHVO-2 reference materials with a new configuration on a $\mathrm{Nu}$ Plasma Multi Collector MC-ICP-MS. Geostandards Geoanal. Res. 32: 193-202, doi:10.1111/j.1751-908X. 2008.00879.x

Altabet, M. A., And R. François. 2001. Nitrogen isotope biogeochemistry of the Antarctic Polar Frontal Zone at 170W. Deep-Sea Res. II 48: 4247-4273, doi:10.1016/S0967-0645 (01)00088-1

BlAIN, S., AND OTHERS. 2007. Effect of natural iron fertilization on carbon sequestration in the Southern Ocean. Nature 446: 1071-1074, doi:10.1038/nature05700

Boyd, P. W., A. C. Crossley, G. R. Ditullio, F. B. Griffiths, D. A. Hutchins, B. Quéguiner, P. N. Sedwick, and T. W. Trull. 2001. Control of phytoplankton growth by iron supply and irradiance in the subantarctic Southern Ocean: Experimental results from the SAZ project. J. Geophys. Res. 106: 31,573-31,583, doi:10.1029/2000JC000348

- AND OTHERs. 2007. Mesoscale iron enrichment experiments 1993-2005: Synthesis and future directions. Science 315: 612-617, doi:10.1126/science. 1131669

Brzezinski, M. A., J. L. Jones, C. P. Beucher, M. S. Demarest, AND H. L. BERg. 2006. Automated determination of silicon isotope natural abundance by the acid decomposition of cesium hexafluosilicate. Anal. Chem. 78: 6109-6114, doi:10.1021/ac0606406

$\longrightarrow,-$ K. D. Bidle, And F. Azam. 2003. The balance between silica production and silica dissolution in the sea: Insights from Monterey Bay, California, applied to the global data set. Limnol. Oceanogr. 48: 1846-1854, doi:10.4319/ lo.2003.48.5.1846

$\longrightarrow$ - $\longrightarrow$ and M. S. Demarest. 2005. Control of silica production by iron and silicic acid during the Southern Ocean Iron Experiment (SOFeX). Limnol. Oceanogr. 50: 810-824, doi:10.4319/lo.2005.50.3.0810

, D. M. Nelson, V. M. Franck, and D. M. Sigmon. 2001. Silicon dynamics within an intense open ocean diatom bloom in the Pacific sector of the Southern ocean. Deep-Sea Res. II 48: 3997-4081, doi:10.1016/S0967-0645(01)00078-9

- AND OTHERs. 2002. A switch of $\mathrm{Si}(\mathrm{OH})_{4}$ to $\mathrm{NO}^{-}{ }_{3}$ depletion in the glacial Southern Ocean. Geophys. Res. Lett. 29: 1564, doi:10.1029/2001GL014349

Buesseler, K. O., L. Ball, J. Andrews, J. K. Cochran, D. J. Hirschberg, M. P. Bacon, A. Fleer, and M. A. Brzezinski. 2001. Upper ocean export of particulate organic carbon and biogenic silica in the Southern Ocean along $170^{\circ} \mathrm{W}$. Deep Sea Res. II 48: 4275-4297, doi:10.1016/S0967-0645(01)00089-3

Cardinal, D., L. Y. Alleman, F. Dehairs, N. Savoye, T. W. Trull, And L. André. 2005. Relevance of silicon isotopes to Si-nutrient utilization and Si-source assessment in Antarctic waters. Glob. Biogeochem. Cycles 19: GB2007, doi:10.1029/ 2004GB002364

, J. De Jong, K. Ziegler, And L. André. 2003. Isotopic composition of silicon measured by multicollector plasma source mass spectrometry in dry plasma mode. J. Anal. Atomic Spectrom. 18: 213-218, doi:10.1039/b210109b

, N. Savoye, T. W. Trull, F. Dehairs, E. E. Kopczynska, F. Fripiat, J. L. Tison, And L. André. 2007. Silicon isotopes in spring Southern Ocean diatoms: Large changes despite homogeneity among size fractions. Mar. Chem. 106: 46-62, doi:10.1016/j.marchem.2006.04.006

Cembella, B., H. Rohr, K. Loquay, and V. H. Strass. 2005. Mapping horizontal spreading of a developing phytoplankton bloom using an airborne chlorophyll $a$ fluorescence LIDAR. Ber. Polar Meeresforsch. 500: 38-43.

Chever, F., G. Sarthou, E. Bucciarelli, S. Blain, and A. R. BowiE. 2010. An iron budget during the natural iron fertilisation experiment KEOPS (Kerguelen Islands, Southern Ocean). Biogeoscience 7: 455-468, doi:10.5194/bg-7-455-2010

Cisewski, B., V. H. Strass, M. Losch, and H. Prandke. 2008. Mixed layer analysis of a mesoscale eddy in the Antarctic Polar Front Zone. J. Geophy. Res. 113: C05017, doi:10.1029/ 2007JC004372

Coale, K. H., AND others. 2004. Southern Ocean Iron Enrichment Experiment: Carbon cycling in high- and low-Si waters. Science 304: 408-414, doi:10.1126/science.1089778

Croot, P. L., U. Passow, P. Assmy, S. Jansen, and V. H StRAss. 2007. Surface active substances in the upper water column during a Southern Iron Fertilization Experiment (EIFeX). Geophys. Res. Lett. 34: L03612, doi:10.1029/ 2006GL028080 
de Batr, H. J. W., L. J. A. Gerringa, P. LaAn, and K. R. Timmermans. 2008. Efficiency of carbon removal per added iron in ocean iron fertilization. Mar. Ecol. Prog. Ser. 364: 269-282, doi: $10.3354 /$ meps 07548

—, AND OTHERs. 2005. Synthesis of iron fertilization experiments: From the Iron Age in the Age of Enlightenment. J. Geophys. Res. 110: C09S16, doi:10.1029/2004JC002601

De La Rocha, C. L., M. A. Brzezinski, and M. J. Deniro. 1996. Purification, recovery, and laser-driven fluorination of silicon from dissolved and particulate silica for the measurement of natural stable isotope abundances. Anal. Chem. 68: 3746-3750, doi:10.1021/ac960326j

— - AND - 1997. Fractionation of silicon isotopes by marine diatoms during silica formation. Geochim. Cosmochim. Acta 61: 5051-5056, doi:10.1016/S0016-7037(97) 00300-1

2000. A first look at distribution of the stable isotopes of silicon in natural waters. Geochim. Cosmochim. Acta 64: 2467-2477, doi:10.1016/S0016-7037(00) 00373-2

$\longrightarrow,-,-$ ANd A. Shemesh. 1998. Silicon-isotope composition of diatoms as an indicator of past oceanic change. Nature 395: 680-683, doi:10.1038/27174

Demarest, M. S., M. A. Brzezinski, and C. P. Beucher. 2009. Fractionation of silicon isotopes during biogenic silica dissolution. Geochim. Cosmochim. Acta 73: 5572-5583, doi:10.1016/j.gca.2009.06.019

Falkowski, P. G., R. T. Barber, And V. Smetacek. 1998. Biogeochemical controls and feedbacks on ocean primary production. Science 281: 200-206, doi:10.1126/science.281.5374.200

Fripiat, F., A.-J. Cavagna, N. Savoye, F. Dehairs, L. André, AND D. CARDInAL. In press. Silicon isotopic constraints on the Si-biogeochemical cycle during KEOPS (Kerguelen Ocean and Plateau study). Mar. Chem. doi:10.1016/j.marchem. 2010.08.005

FRY, B. 2006. Stable isotope ecology. Springer.

Grasshoff, K., M. Erhardt, and K. Kremling. 1983. Methods of seawater analysis, second Ed. Verlag Chemie.

Hansen, H. P., ANd F. KorolefF. 1999. Determination of nutrients, p. 159-228. In K. Grasshoff, K. Kremling, and M. Ehrhard [eds.], Methods of seawater analyses. WileyVHC.

Hoffmann, L. J., I. Peeken, and K. Lochte. 2007. Effects of iron on elemental stoichiometry during EIFEX and in the diatoms Fragilariopsis kerguelensis and Chaetoceros dichaeta. Biogeoscience 4: 569-579, doi:10.5194/bg-4-569-2007

——, - P. Assmy, And M. Veldhuis. 2006. Different reactions of Southern Ocean phytoplankton size classes to iron fertilization. Limnol. Oceanogr. 51: 1217-1229, doi:10.4319/1o.2006.51.3.1217

Jacquet, S. H. M., N. Savoye, F. Dehairs, F. H. Strass, and D. Cardinal. 2008. Mesopelagic carbon remineralization during the European Iron Fertilization Experiment. Glob. Biogeochem. Cycles 22: GB1023, doi:10.1029/ 2006GB002902

Jin, X., N. Gruber, J. P. Dunne, J. L. Sarmiento, and R. A. Armstrong. 2006. Diagnosing the contribution of phytoplankton functional groups to the production and export of particulate organic carbon, $\mathrm{CaCO}_{3}$, and opal from global nutrient and alkalinity distributions. Glob. Biogeochem. Cycles 20: GB2015, doi:10.1029/2005GB002532

Karl, D. M., and G. Tien. 1992. MAGIC: A sensitive and precise method for measuring dissolved phosphorus in aquatic environments. Limnol. Oceanogr. 37: 105-106, doi:10.4319/ 10.1992.37.1.0105
Marchetti, A., D. E. Varela, V. P. Lance, Z. Johnson, M. Palmucci, M. Giordano, and E. V. Armbrust. 2010. Iron and silicic acid effects on phytoplankton productivity, diversity, and chemical composition in the central equatorial Pacific Ocean. Limnol. Oceanogr. 55: 11-29.

Mariotti, A., J. C. Germon, P. Hubert, P. Kaiser, R. Letolle, A. Tardieux, And P. Tardieux. 1981. Experimental determination of nitrogen kinetic isotope fractionation: Some principles - illustration for the denitrification and nitrification processes. Plant Soil. 62: 413-430, doi:10.1007/ BF02374138

Martin, J. H. 1990. Glacial-interglacial change: The iron hypothesis. Paleoceanography 5: 1-13, doi:10.1029/ PA005i001p00001

McGuillicudy, D. J., AND others. 1998. Influence of mesoscale eddies on new production in the Sargasso Sea. Nature 394: 263-266, doi:10.1038/28367

Measures, C. I., And S. Vink. 2001. Dissolved Fe in upper Twaters of the Pacific sector of the Southern Ocean. Deep-Sea Res. II 48: 3913-3941, doi:10.1016/S0967-0645(01) 00074-1

Milligan, A. J., D. E. Varela, M. A. Brzezinski, and F. M. M. Morel. 2004. Dynamics of silicon metabolism and silicon isotopic discrimination in a marine diatom as a function of $\mathrm{pCO}_{2}$. Limnol. Oceanogr. 49: 322-329, doi:10.4319/ lo.2004.49.2.0322

Nelson, D. M., P. Tréguer, M. A. Brzezinski, A. Leynaert, And B. Quéguiner. 1995. Production and dissolution of biogenic silica in the ocean: Revised global estimates, comparison with regional data and relationship to biogenic sedimentation. Glob. Biogeochem. Cycles 9: 359-372, doi:10.1029/ 95GB01070

Pollard, R. T., R. Sanders, M. Lucas, and P. Statham. 2007. The Crozet natural iron bloom and export experiment (CROZEX). Deep-Sea Res. II 54: 1905-1914, doi:10.1016/ j.dsr2.2007.07.023

, AND OTHERS. 2009. Southern Ocean deep-water carbon export enhanced by natural iron fertilization. Nature 457: 577-580, doi:10.1038/nature07716

Quéguiner, B., AND M. A. Brzezinski. 2002. Biogenic silica production rates and particulate organic matter distribution in the Atlantic sector of the Southern Ocean during austral spring 1992. Deep-Sea Res. II 49: 1765-1786, doi:10.1016/ S0967-0645(02)00011-5

- P. Tréguer, I. Peeken, and R. Scharek. 1997. Biogeochemical dynamics and the silicon cycle in the Atlantic sector of the Southern Ocean during austral spring 1992. Deep-Sea Res. II 44: 69-89, doi:10.1016/S0967-0645(96) 00066-5

Ragueneau, O., N. Savoye, Y. Del Amo, J. Cotton, B. Tardiveau, and A. Leynaert. 2005. A new method for the measurement of biogenic silica in suspended matter of coastal waters: Using $\mathrm{Si}: \mathrm{Al}$ ratios to correct for the mineral interference. Cont. Shelf. Res. 25: 697-710, doi:10.1016/ j.csr.2004.09.017

, S. Schultes, K. Bidle, P. Claquin, and B. Moriceau. 2006. Si and $\mathrm{C}$ interactions in the world ocean: Importance of ecological processes and implications for the role of diatoms in the biological pump. Glob. Biogeochem. Cycles 20: GB4S02, doi:10.1029/2006GB002688

Reynolds, B. C., AND OTHERs. 2007. An inter-laboratory comparison of $\mathrm{Si}$ isotope reference materials. J. Anal. Atomic Spect. 22: 561-568, doi:10.1039/b616755a

Röttgers, R., F. Colijn, And M. Dibbern. 2005. Algal physiology and biooptics. Ber. Polar Meeresforsch. 500: 82-88. 
Sarmiento, J. L., N. Gruber, M. A. Brzezinski, and J. P. Dunne. 2004. High latitudes controls of thermocline nutrients and low latitude biological productivity. Nature 427: 56-60, doi:10.1038/nature02127

Sedwick, P. N., A. R. Bowie, And T. W. Trull. 2008. Dissolved iron in the Australian sector of the Southern Ocean (CLIVAR SR3 section): Meridional and seasonal trends. Deep-Sea Res. I 55: 911-925, doi:10.1016/j.dsr.2008.03.011

Sigman, D. M., M. A. Altabet, D. C. McCorkle, R. François, AND G. Fischer. 1999. The $\delta^{15} \mathrm{~N}$ of nitrate in the Southern Ocean: Consumption of nitrate in surface waters. Glob. Biogeochem. Cycles 13: 1149-1166, doi:10.1029/ 1999GB900038

Strass, V., B. Cisewski, S. Gonzales, H. Leach, K.-D. Loquay, H. PrandKe, H. Rohr, and M. Thomas. 2005. The physical setting of the European Iron Fertilization Experiment "EIFEX" in the Southern Ocean. Rep. Polar Mar. Res. 500: 15-46.

TAKEDA, S. 1998. Influence of iron availability on nutrient consumption ratio of diatoms in oceanic waters. Nature 393: 774-777, doi:10.1038/31674

Trull, T. W., S. R. Rintoul, M. Hadfield, and E. R. Abraham. 2001. Circulation and seasonal evolution of polar waters south of Australia: Implications for iron fertilization of the Southern Ocean. Deep-Sea Res. II 48: 2439-2466, doi:10.1016/S0967-0645(01)00003-0
Varela, D. E., C. J. Pride, and M. A. Brzezinsiki. 2004 Biological fractionation of silicon isotopes in Southern Ocean surface waters. Glob. Biogeochem. Cycles 18: GB1047, doi:10.1029/2003GB002140

Watson, A. J., D. C. E. Bakker, A. J. Ridgwell, P. W. Boyd, AND C. S. LAw. 2000. Effect of iron supply on Southern Ocean $\mathrm{CO}_{2}$ uptake and implications for glacial atmospheric $\mathrm{CO}_{2}$. Nature 407: 730-733, doi:10.1038/35037561

Whitworth, T., AND W. D. Nowlin. 1987. Water masses and currents of the Southern Ocean at the Greenwich meridian. J. Geophys. Res. 92: 6462-6476, doi:10.1029/JC092iC06p06462

Young, E. D., A. Galy, and H. Nagahara. 2002. Kinetic and equilibrium mass dependant isotope fractionation laws in nature and their geochemical and cosmochemical significance. Geochim. Cosmochim. Acta 66: 1095-1104, doi:10.1016/ S0016-7037(01)00832-8
Associate editor: Heidi M. Sosik

Received: 09 May 2010 Accepted: 29 September 2010 Amended: 13 October 2010 